\title{
ROS mediated DNA damage and induction of apoptosis in cervical cancer cells by Heliotropium indicum L.
}

\author{
Subhabrata Paul, Rita Kundu* \\ Centre of Advanced Study, Department of Botany, University of Calcutta, Kolkata, West Bengal, India.
}

\section{ARTICLE INFO \\ Article history: \\ Received on: 26/12/2017 \\ Accepted on: 12/06/2018 \\ Available online: $31 / 08 / 2018$}

\section{Key words:}

Apoptosis, ROS, DNA

damage, Cervical cancer,

Heliotropium indicum.

\begin{abstract}
Objective: In Indian sub-continent occurrence of cervical cancer is second among women. Most cervical cancer cases are associated with HPV 16. In this study, the anti-proliferative activity of chloroform fraction of methanolic extract of Heliotropium indicum was studied in a panel of cervical cancer cell lines. Methods: HeLa (HPV 18 positive), SiHa (HPV 16 positive) and C33A (HPV negative) cells were treated with $\mathrm{IC}_{50}$ doses and experiments were performed to evaluate the cell death process. To chemically characterize the extract fraction, GC-MS, LC-MS and column chromatography were performed. Results: Typical apoptotic features were found in the treated cells. Most cells were found in late apoptotic stages. In HeLa and C33A cell lines, cells were blocked at G1/S, in SiHa, subG0 population increased. Expression of anti-apoptotic Bcl-2 decreased and that of pro-apoptotic BAX, p53, p21 increased. Expression of HPV16 and human ET-1 also decreased. ROS mediated DNA damage was detected. Different fatty acids along with other compounds like phenolics, alkaloids were detected in the chloroform fraction, all of which are reported to have anticancer properties. Conclusion: From the study, it can be concluded that fatty acid rich chloroform fraction of $H$. indicum is capable of inducing apoptosis in cervical cancer cells, through ROS mediated DNA damage.
\end{abstract}

\section{INTRODUCTION}

Members of heliotropes (Heliotropium indicum, $H$. ovalifolium, $H$. ramosissimum, $H$. steudneri) are used as medicine traditionally in the pantropical regions, where they are found in abundance. Mostly the plants are used to treat snakebite/scorpion stings, indicating their antitoxin activity (Duttagupta et al., 1977). Leaf poultices/juices and infusions are used to treat dandruff, skin ailments, kidney dysfunction, and fever. For centuries, these plants were used as an analgesic, diuretic, and cleanser of wounds by the African people (Togola et al., 2005). H. indicum, commonly known as Indian heliotrope is widely distributed throughout Indian subcontinent though they are probably native to tropical America. In Rajanighantu - an important lexicon of Ayurvedic materia media written in the $12^{\text {th }} / 13^{\text {th }}$ century, the curative property of $H$. indicum (hatisundi) against typhoid was mentioned (Karra, 2013). The whole plant is used as diuretic and anodyne, seeds are used

${ }^{*}$ Corresponding Author

Rita Kundu, Centre of Advanced Study, Department of Botany,

University of Calcutta, 35, Ballygunge Circular Road, Kolkata 700019,

West Bengal, India.E-mail: kundu_rita@yahoo.co.in in stomachache; leaf juices are specially used in conjunctivitis and locally applied in boils, gingivitis, pimples, sores, ulcers and wounds (Dash et al., 2013). In recent times researches are going onto establishing the value of traditional medicinal plants by experimental evidence, which showed the wound healing (Reddy et al., 2002) and antimicrobial activity of $H$. indicum (Oluwatoyin et al., 2011). This plant is reported to contain pyrrolizidine alkaloids such as indicine, indicine $\mathrm{N}$ oxide, acetyl indicine, indicinine, helecerine, heliotrine, supinine, lindelofidine, all of which are reported to be hepatotoxic (Roeder et al., 2011).

In the present study, we tried to evaluate this traditional medicinal plant against cervical cancer cells. Cancer cells are characterized by dysregulated cell division resulting in uncontrolled cell proliferation and lack of apoptosis leading to immortality. Therefore, targeted cell death is used as a therapy to control such cells. For our study, we have taken three cervical cancer cell lines, $\mathrm{HeLa}$ (HPV 18 positive), SiHa (HPV 16 positive) and C33A (HPV negative) to compare the extract's efficacy on HPV positive and HPV negative cells. At the same time, we also tried to study the cell death pathway induced in the cell lines by the plant extract. 


\section{MATERIAL AND METHODS}

Preparation of plant extract, fractionation of the extract, culture of cells and determination of $\mathrm{IC}_{50}$ doses in different cell lines was described previously (Paul et al., 2015). All the experiments were conducted with the $\mathrm{IC}_{50}$ doses at different time points.

\section{Cellular and nuclear morphology}

Around $5 \times 10^{3}$ cells per coverslip (pre-coated with L-Lysine, Sigma) were seeded overnight and then treated with $\mathrm{IC}_{50}$ doses for $24 \mathrm{~h}$. Then cells were briefly washed, fixed with $4 \%$ PFA and washed again with chilled PBS and stained with Hoechst 33258 (Sigma) for $2 \mathrm{~min}$ at room temperature at a concentration of $2 \mu \mathrm{g} / \mathrm{ml}$. After further washing with PBS, cells were mounted in PBS:Glycerol = 1:9 containing propyl gallate.

\section{Apoptosis assay (annexin V-FITC/PI double staining)}

Around $5 \times 10^{5}$ cells per T-25 flask were seeded for overnight and then treated with the $\mathrm{IC}_{50}$ doses $24 \mathrm{~h}$. Then cells were harvested, washed with PBS, stained with Annexin V-FITC antibody and propidium iodide for $15 \mathrm{~min}$ at dark according to manufacturer's protocol (BD Biosciences) and subjected to flow cytometry (BD FACS Verse).

\section{Cell cycle shift}

Around $5 \times 10^{5}$ cells per T-25 flask were seeded for overnight and then treated with the $\mathrm{IC}_{50}$ doses $24 \mathrm{~h}$. Then cells were harvested, washed with PBS, fixed with $70 \%$ ethanol, treated with RNase A at $37^{\circ} \mathrm{C}$ for $2 \mathrm{~h}$, and then stained with PI, incubated at dark for $15 \mathrm{~min}$ and subjected to flow cytometry.

\section{Gene expression study by semi Q RT-PCR}

After $24 \mathrm{~h}$ treatment with $\mathrm{IC}_{50}$ doses, cells were harvested and washed with PBS. Total RNA was isolated from the cells using Tri-reagent (Sigma) following manufacturer's protocol. The integrity of the RNA samples was checked by bleach gel (Aranda et al., 2012) and quantified by UV spectroscopy. cDNA was prepared with $1 \mu \mathrm{g}$ RNA as starting material using first strand cDNA synthesis kit (Thermo Scientific), following manufacturer's protocol. $1 \mu \mathrm{l}$ of that cDNA was taken to do PCRs for several apoptotic genes with GAPDH as an internal control. Primer 3 software was used to design primers. The primer sequences and PCR profiles were given in Table 1 . PCR products were run in $2 \%$ agarose gels and photographed in gel documentation system (UVP MultiDoc-It). NIH-ImageJ software was used for the densitometric analysis to calculate relative densities of the gene expression with respect to the non-treated sets. The primer sequences and PCR profiles were listed in Table 1.

\section{Protein expression study by immunoblotting}

Total protein was extracted by lysing treated cells with $1 \mathrm{X}$ sample loading buffer. $50 \mu \mathrm{g}$ protein of each set was run in 10 or $12 \%$ polyacrylamide gels. Then, proteins were blotted in nitrocellulose membrane (Pall- $0.22 \mu \mathrm{m}$ ) and blocked with $5 \%$ BSA for $3 \mathrm{~h}$ at room temperature. Then the blots were subsequently incubated with primary antibodies for overnight at $4{ }^{\circ} \mathrm{C}$ with gentle shaking. Then washed with TBS-T (Tris-buffered saline with $0.05 \%$ Tween 20 buffer) and incubated with AP-conjugated secondary antibody for $3 \mathrm{~h}$ at room temperature. Then washed well with TBS-T and TBS and incubated with the substrate NBTBCIP (Sigma) until bands appear. After the appearance of bands, the reaction was stopped with water and photographed in gel documentation system (UVP-multidoc It). Antibody specifications and respective dilutions were given in Table 2.

\section{ROS generation}

After a brief treatment of $3 \mathrm{~h}$, cells were stained with $\mathrm{H}_{2}$ DCFDA (Abcam) for $30 \mathrm{~min}$ at $37^{\circ} \mathrm{C}$ and then washed with PBS and visualized under an epi-fluorescent microscope (Leica).

\section{Loss of mitochondrial membrane potential}

After a brief treatment of $4 \mathrm{~h}$, cells were stained with JC1 (BD Biosciences) for $15 \mathrm{~min}$ at $37^{\circ} \mathrm{C}$ and washed with PBS and visualized under an epi-fluorescent microscope (Leica).

\section{ROS mediated DNA damage}

\section{Incorporation of $\gamma H 2 A X$}

After a brief treatment of $6 \mathrm{~h}$, cells were fixed with $4 \%$ PFA at room temperature for $15 \mathrm{~min}$, washed, incubated overnight with the anti- $\gamma \mathrm{H} 2 \mathrm{AX}$ antibody (Cell signaling technology) at $4{ }^{\circ} \mathrm{C}$ in a humidified container. Then washed with PBS and incubated with FITC conjugated antibody for $3 \mathrm{~h}$ at room temperature, rewashed with PBS, mounted in mounting medium (PBS:Glycerol $=1: 9$ ) containing propyl gallate and visualized under an epifluorescent microscope (Leica). Antibody specifications and respective dilutions were given in Table 2.

\section{Western blot of DNA damage responsive proteins}

Western Blots were performed as described in the earlier section. Antibody specifications and respective dilutions were given in Table 2.

\section{GC-MS}

Samples were TMS-derivatized with BSTFA (Sigma) and injected in HP5-MS capillary column $(30 \mathrm{~m} \times 0.25 \mathrm{~mm} \times 0.25$ $\mu \mathrm{m})$ and run through a temperature gradient of $70-260^{\circ} \mathrm{C}$ with a ramping rate of $5^{\circ} \mathrm{C}$ per min [Agilent]. Fragmentation pattern of the peaks was matched with NIST library.

\section{LC-MS/MS}

The chloroform fraction was dried under a gentle stream of nitrogen and reconstituted in methanol. The compounds present in the extract were analyzed by LC-MS/MS. The UPLC system was coupled to a hybrid quadrupole, orthogonal timeof-flight (Q-TOF) tandem mass spectrometer (SYNAPT G2 HDMS, Waters, Manchester, U.K.) equipped with ESI. The chromatographic separation was performed on an Acquity UPLC BEH C18 Column $(3.0 \mathrm{~mm} \times 150 \mathrm{~mm}, 1.7 \mu \mathrm{m}$, waters, Ireland $)$ at a temperature of $40^{\circ} \mathrm{C}$. The mobile phases consisted of eluent $\mathrm{A}$ $(0.1 \%$ formic acid in water, $\mathrm{v} / \mathrm{v})$ and eluent $\mathrm{B}(0.1 \%$ formic acid in acetonitrile, $\mathrm{v} / \mathrm{v})$. These eluents were delivered at a flow rate of $0.4 \mathrm{~mL} / \mathrm{min}$ with a linear gradient program as follows: $20-80 \% \mathrm{~B}$ from 0 to $15 \mathrm{~min}, 80-95 \%$ B from 15.0 to $15.5 \mathrm{~min}$, held at $95 \% \mathrm{~B}$ from 15.5 to $18.0 \mathrm{~min}, 95-20 \% \mathrm{~B}$ from 18.0 to $19.0 \mathrm{~min}$ and held at $25 \% \mathrm{~B}$ from 19.0 to $20.0 \mathrm{~min}$. The operating parameters were as follows: capillary voltage of $3 \mathrm{kV}(\mathrm{ESI}+)$, sample cone voltage of 
$35 \mathrm{~V}$, extraction cone voltage of $4 \mathrm{~V}$, source temperature of $100^{\circ} \mathrm{C}$, desolvation temperature of $300^{\circ} \mathrm{C}$, cone gas flow of $50 \mathrm{~L} / \mathrm{h}$ and desolvation gas flow of $800 \mathrm{~L} / \mathrm{h}$. In $\mathrm{MS}^{\mathrm{E}}$ mode, the trap collision energy for the low-energy function was set at $5 \mathrm{eV}$, while the ramp trap collision energy for the high-energy function was set at 20-50 $\mathrm{eV}$. Argon was used as the collision gas for collision-induced dissociation (CID) in MSE mode. To ensure mass accuracy and reproducibility, the mass spectrometer was calibrated over a range of 50-1500 Da using a solution of sodium formate. Searching with several popular databases (ReSpect, MassBank, MZ cloud etc.) several compounds were identified.

Table 1: Primer sequences and PCR profiles of the genes analyzed in RT-PCR.

\begin{tabular}{|c|c|c|c|c|c|c|c|}
\hline \multirow{2}{*}{ Gene } & \multicolumn{7}{|c|}{ Primer sequence $\left(5^{\prime} \rightarrow 3^{\prime}\right)$} \\
\hline & \multicolumn{3}{|c|}{ Forward } & \multicolumn{4}{|c|}{ Reverse } \\
\hline $\mathrm{p} 53$ & \multicolumn{3}{|c|}{ ATGGCCATCTACAAGCAG } & \multicolumn{4}{|c|}{ ACAGTCAAGAGCCAACCTCAG } \\
\hline BAX & \multicolumn{3}{|c|}{ GTGGCAGCTGACATGTTTTC } & \multicolumn{4}{|c|}{ GGAGGAAGTCCAATGTCCAG } \\
\hline Bcl-2 & \multicolumn{3}{|c|}{ GGGTACGATAACCGGGAGAT } & \multicolumn{4}{|c|}{ CTGAAGAGCTCCTCCACCAC } \\
\hline ET-1 & \multicolumn{3}{|c|}{ TCCTCTGCTGGTTCCTGACT } & \multicolumn{4}{|c|}{ CAGAAACTCCACCCCTGTGT } \\
\hline HPV 18 E6 & \multicolumn{3}{|c|}{ TGAAAAACGACGATTCCACA } & \multicolumn{4}{|c|}{ TTGTGTTTCGCGTCGTT } \\
\hline GAPDH & \multicolumn{3}{|c|}{ CAAGGTCATCCATGACAACTTTG } & \multicolumn{4}{|c|}{ GTCCACCACCCTGTTGCTGTAG } \\
\hline \multicolumn{8}{|c|}{ PCR profile } \\
\hline & $\begin{array}{l}\text { Initial denaturation } \\
\left({ }^{\circ} \mathrm{C} \text { - minutes) }\right.\end{array}$ & $\begin{array}{l}\text { Denaturation } \\
\left({ }^{\circ} \mathrm{C} \text { - seconds) }\right.\end{array}$ & $\begin{array}{l}\text { Annealing } \\
\left({ }^{\circ} \mathrm{C} \text { - seconds) }\right.\end{array}$ & $\begin{array}{l}\text { Extension } \\
\left({ }^{\circ} \mathrm{C} \text { - seconds) }\right.\end{array}$ & $\begin{array}{l}\text { Number of } \\
\text { cycles }\end{array}$ & $\begin{array}{l}\text { Final extension } \\
\left({ }^{\circ} \mathrm{C} \text { - minutes }\right)\end{array}$ & $\begin{array}{l}\text { Product } \\
\text { length (bp) }\end{array}$ \\
\hline ET-1 & \multirow{4}{*}{$94-4$} & \multirow{4}{*}{$94-30$} & $57-30$ & $72-45$ & \multirow{4}{*}{35} & \multirow{4}{*}{$72-7$} & 242 \\
\hline HPV 16 E6 & & & $52-30$ & $72-30$ & & & 106 \\
\hline HPV 18 E6 & & & $53-30$ & $72-30$ & & & 285 \\
\hline GAPDH & & & $58-30$ & $72-45$ & & & 496 \\
\hline
\end{tabular}

Table 2: Specifications of antibodies, along with their respective dilutions.

\begin{tabular}{|c|c|c|c|c|c|}
\hline Protein & Manufacturer & Code & Reactivity & Dilution & Experiment \\
\hline Caspase-3 & Cell Signalling Technology & 9665 & Rabbit monoclonal & $1: 1000$ & \multirow{13}{*}{ Western Blot } \\
\hline BAX & \multirow{4}{*}{ Santa Cruz Biotechnology } & Sc-7480 & & & \\
\hline Bcl-2 & & Sc-509 & & & \\
\hline p53 & & Sc-126 & Mouse monoclonal & $1: 500$ & \\
\hline p21 & & Sc-6246 & & & \\
\hline HPV 16/18 E6 & AbCam & $\mathrm{Ab}-70$ & & & \\
\hline ß-tubulin & Sigma & $\mathrm{T} 8328$ & Mouse monoclonal & $1: 5000$ & \\
\hline p-ATR & & 2853 & \multirow{4}{*}{ Rabbit polyclonal (p-ATM monoclonal) } & \multirow{4}{*}{$1: 1000$} & \\
\hline p-ATM & \multirow{3}{*}{ Cell Signalling Technology } & 5883 & & & \\
\hline p-Chk1 & & 2349 & & & \\
\hline p-Chk2 & & 2661 & & & \\
\hline Goat anti-Rabbit IgG - AP & Santa Cruz Biotechnology & Sc-2007 & Rabbit & \multirow{2}{*}{$1: 5000$} & \\
\hline Goat anti-Mouse IgG - AP & Enzo Life Science & ADI-SAB-101 & Mouse & & \\
\hline$\gamma-\mathrm{H} 2 \mathrm{AX}$ & Cell Signalling Technology & 9718 & Rabbit monoclonal & \multirow{2}{*}{$1: 50$} & \multirow{2}{*}{$\begin{array}{l}\text { Indirect Immuno } \\
\text { fluoresence }\end{array}$} \\
\hline Goat anti-Rabbit oIgG-FITC & Sigma & F0382 & Rabbit & & \\
\hline
\end{tabular}

\section{Column chromatography \& GC-MS}

Chloroform fraction of the extract was concentrated in a rotary evaporator, mixed with silica gel (60-120) to make a slurry and loaded in a glass column packed with silica gel (60-120) and eluted with hexane, ethyl acetate, and methanol in increasing order of polarity. Fractions were collected for $1 / 2$ of column bed volume, concentrated, separated by thin layer chromatography and pooled if necessary. With the pooled fractions, cytotoxicity assay (MTT 
assay) was performed to identify the cytotoxic subfractions. MTT assay was performed with a single dose same as that of the IC50 values of HIC in different cell lines. With those doses, it was checked whether cells were dead $50 \%$ or more (data not shown). Positive samples were subjected to GC-MS analysis as described in the earlier section.

\section{Statistical analysis}

All experiments were performed in triplicates. Average and SD values were calculated by Microsoft Excel. Graph and charts were prepared by Microsoft Excel and GraphPad Prism5. ANOVAs and T-Tests were done by GraphPad Prism5.

\section{RESULT}

\section{Cellular and nuclear morphology}

In all the treated cells, drastic changes in cellular and nuclear morphology were observed. All the treated sets showed characteristic apoptotic features. Membrane shrinkages along with cytoplasmic blebbings were seen. Chromatin condensations along with nuclear fragmentations were seen by Hoechst 33258 staining (Figures 1, 2, and 3).
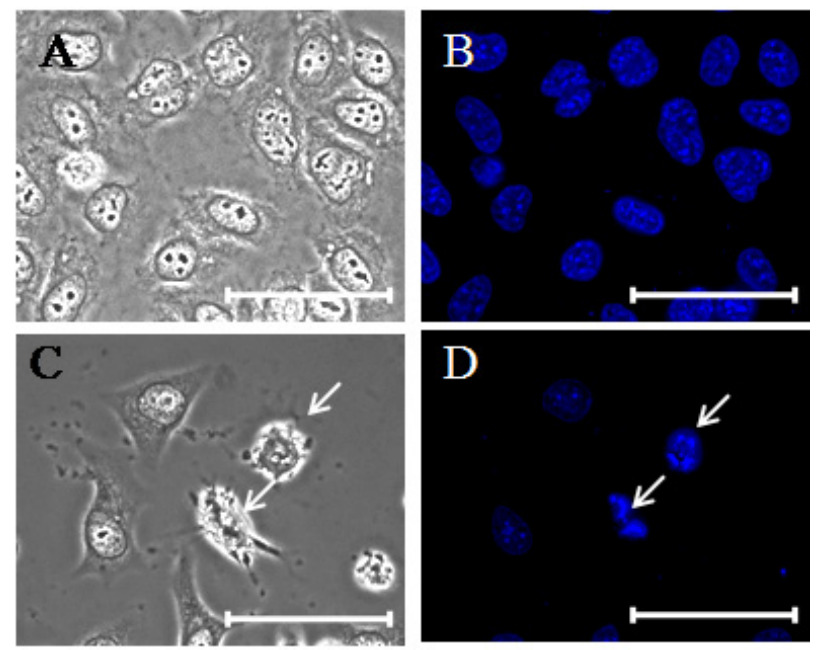

Fig. 1: Effect of HIC fraction on cellular and nuclear morphology of HeLa cells. Arrows show apoptotic features. Scale represents $50 \mu \mathrm{m}$. A \& B: Phase and fluorescent pictures of control cells. C \& D: Phase and fluorescent pictures of treated cells.

\section{Apoptosis assay (annexin V-FITC/PI double staining)}

In HeLa cells, 10.54\% apoptotic cells were found in control cells. HIC treated HeLa cells showed an increase of 4.41 fold with $46.52 \%$ apoptotic cells (Figure 4). In $\mathrm{SiHa}$ cells the $16.01 \%$ apoptotic cells were found in control cells while $42.26 \%$ apoptotic cells were found in HIC treated cells with an increase of 2.64 fold increase (Figure 5). In C33A cells, 9.92 fold increase in apoptotic cell population was observed with $7.73 \%$ and $76.65 \%$ apoptotic cells in control and treated sets respectively (Figure 6).

\section{Cell cycle shift}

With HIC treatment, two types of responses were found in the cell lines. In HeLa and C33A cell lines, sub G0 population was increased suggesting cytotoxicity whereas, in SiHa cells, G1/S block was observed. In HeLa cells, G0G1 decreased by $3.66 \%$ with $8.64 \%$ increase in subG0 population (Figure 7). C33A cells showed similar effect with $18.62 \%$ decrease in G0G1 and increase of $15.22 \%$ in sub G0 population (Figure 9). But in SiHa cells, G0G1 population was increased significantly by $4.65 \%$ (Figure 8 ).
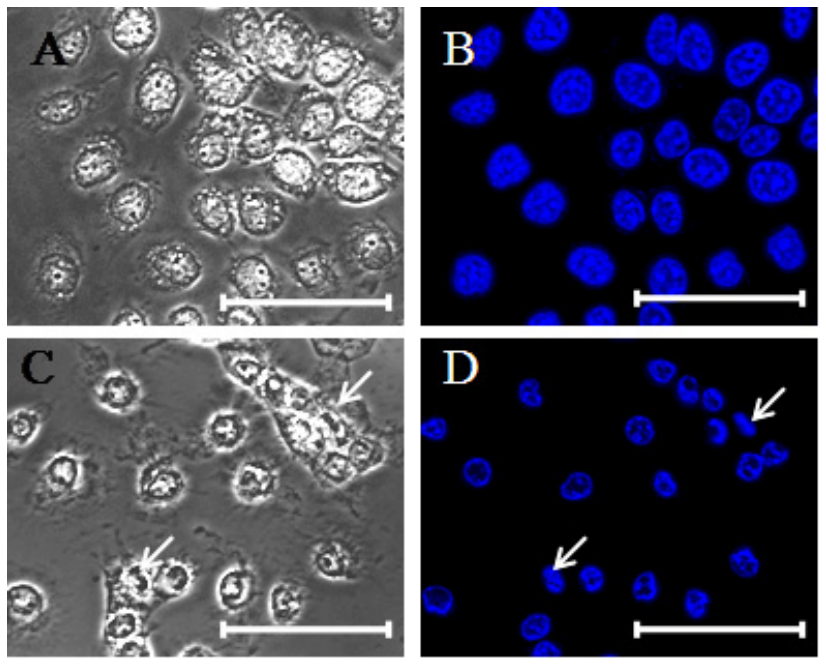

Fig. 2: Effect of HIC fraction on cellular and nuclear morphology of SiHa cells. Arrows show apoptotic features. Scale represents $50 \mu \mathrm{m}$. A \& B: Phase and fluorescent pictures of control cells. C \& D: Phase and fluorescent pictures of treated cells.
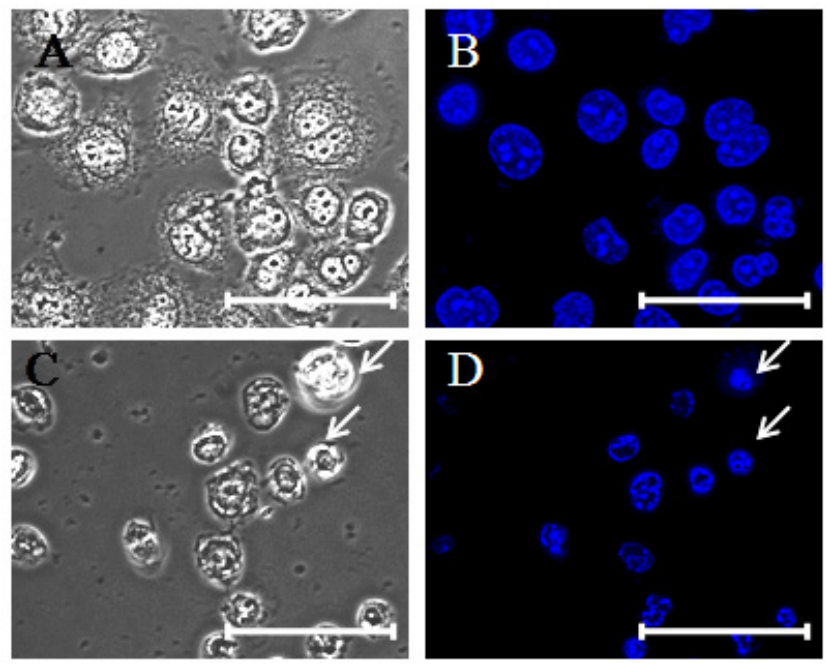

Fig. 3: Effect of HIC fraction on cellular and nuclear morphology of C33A cells Arrows show apoptotic features. Scale represents $50 \mu \mathrm{m}$. A \& B: Phase and fluorescent pictures of control cells. C \& D: Phase and fluorescent pictures of treated cells.

\section{Gene expression study}

Gene expression study revealed changes in expression profiles of various genes. Increased expressions of pro-apoptotic genes were observed. At the same time, anti-apoptotic, proliferation helping genes and viral oncogenes were downregulated. In HeLa cells, a decrease of 0.33 fold, 0.12 fold and 0.63 fold were found for Bcl-2, ET-1, and HPV 18 E6 genes respectively. Expression of p53 increased highly ( 0.93 fold) while BAX and p21 expression increased 0.34 fold and 0.008 fold respectively (Figure 10). In 
SiHa cells, Bcl-2 expression reduced highly (0.87 fold), while expressions of ET-1 and HPV 16 E6 were decreased slightly $(0.1$ and 0.11 folds respectively). BAX expression was increased highly ( 0.77 fold) with 0.36 fold increase in p53 and a slight increase of 0.13 fold for $\mathrm{p} 21$ (Figure 11). In C33A cells, Bcl-2 expression decreased 0.15 fold while BAX, p53, and p21 expressions were increased by 1.09 fold, 1.9 fold, and 1.25 fold respectively (Figure 12). Cell lines without HPV viral load generally didn't express ET-1. No expression of ET-1 was detected as expected in C33A cells.
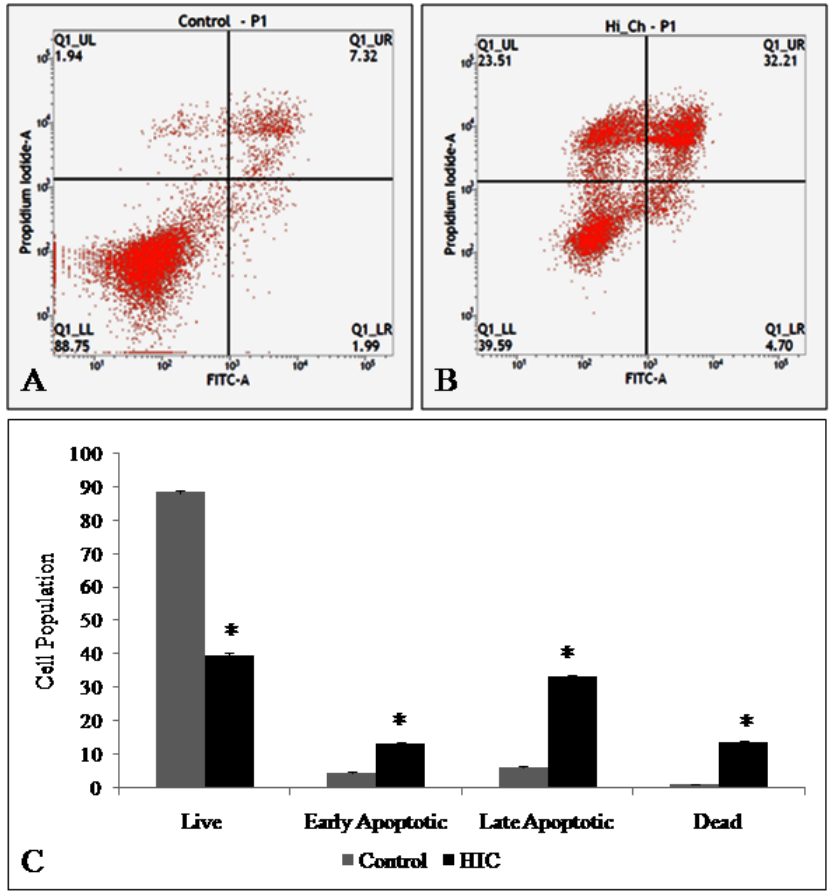

Fig. 4: Representative dot plots [A) Control, B) HIC] along with Bar graph [C] showing cell distribution in different sets of HeLa cells after Annexin V-FITC/PI staining; columns represent the cell populations while bars represent standard deviations. * denotes significant difference between control and treated sets $(\mathrm{P}<0.05)$ [T-Test-GraphPad Prism5].
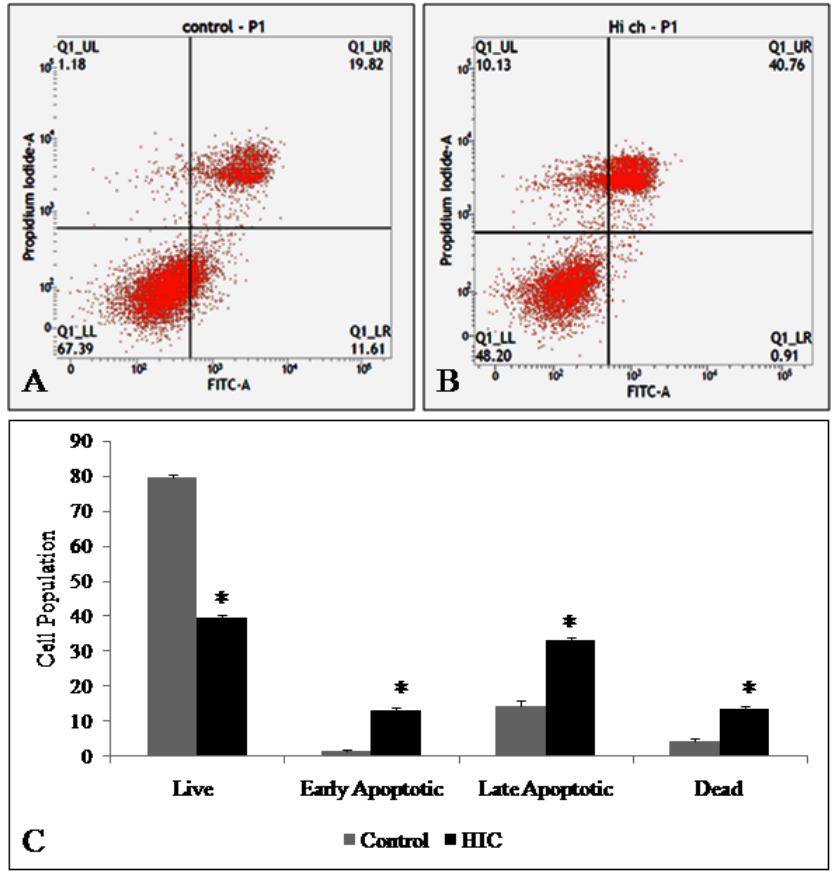

Fig. 5: Representative dot plots [A) Control, B) HIC] along with Bar graph [C] showing cell distribution in different sets of SiHa cells after Annexin V-FITC/PI staining; columns represent the cell populations while bars represent standard deviations. $*$ denotes significant difference between control and treated sets $(\mathrm{P}<0.05)[\mathrm{T}-\mathrm{Test}-$ GraphPad Prism5]. 

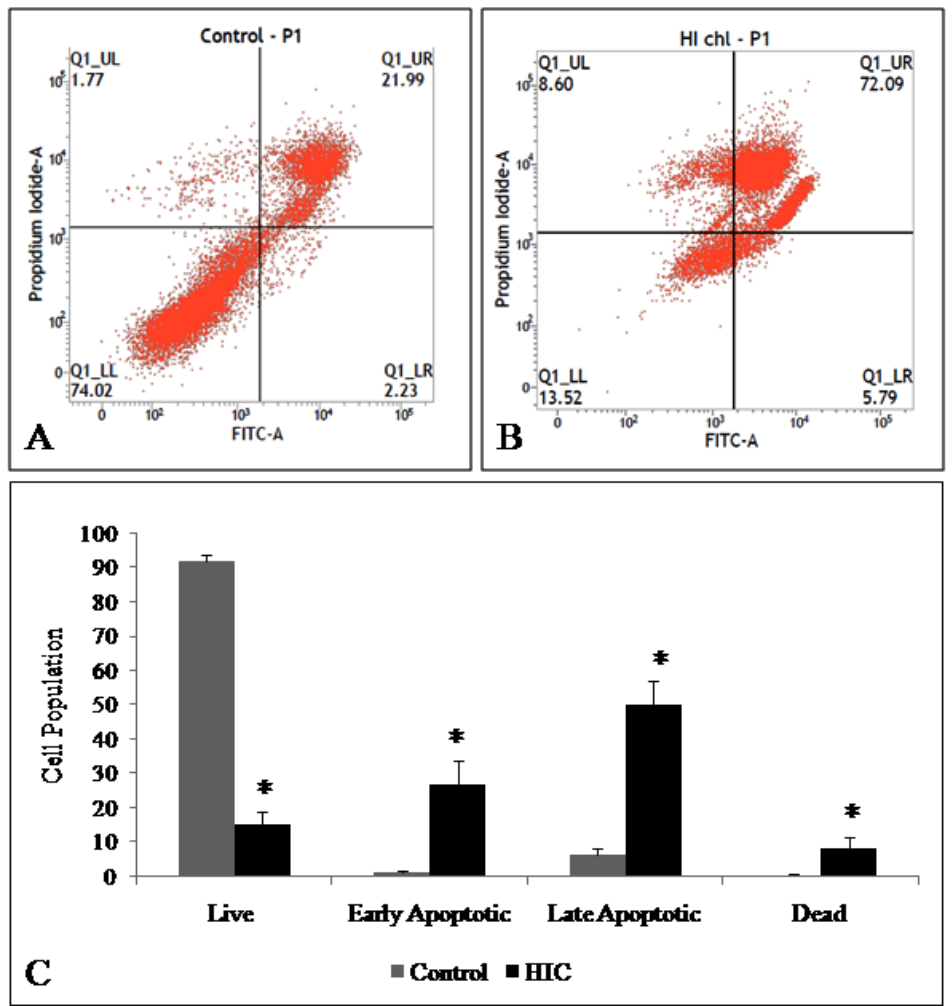

Fig. 6: Representative dot plots [A) Control, B) HIC] along with Bar graph [C] showing cell distribution in different sets of C33A cells after Annexin V-FITC/PI staining; columns represent the cell populations while bars represent standard deviations. $*$ denotes significant difference between control and treated sets $(\mathrm{P}<0.05)$ [T-Test-GraphPad Prism5].
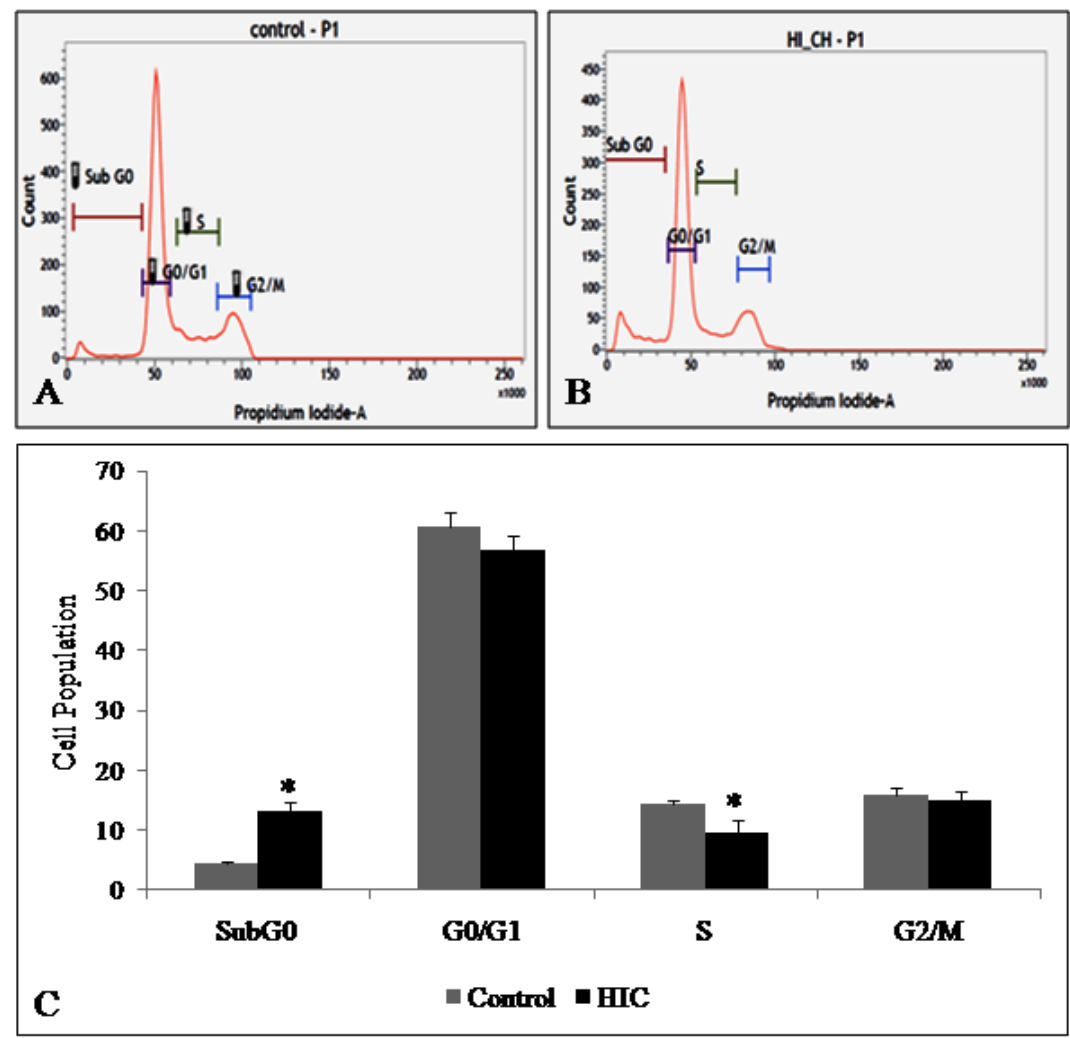

Fig. 7: Representative histograms [A) Control, B) HIC] along with Bar graph [C] showing cell distribution in different phases in sets of HeLa cells; columns represent the cell populations while bars represent standard deviations. * denotes significant difference between control and treated sets $(\mathrm{P}<0.05)[\mathrm{T}-\mathrm{Test}-\mathrm{GraphPad}$ Prism5]. 

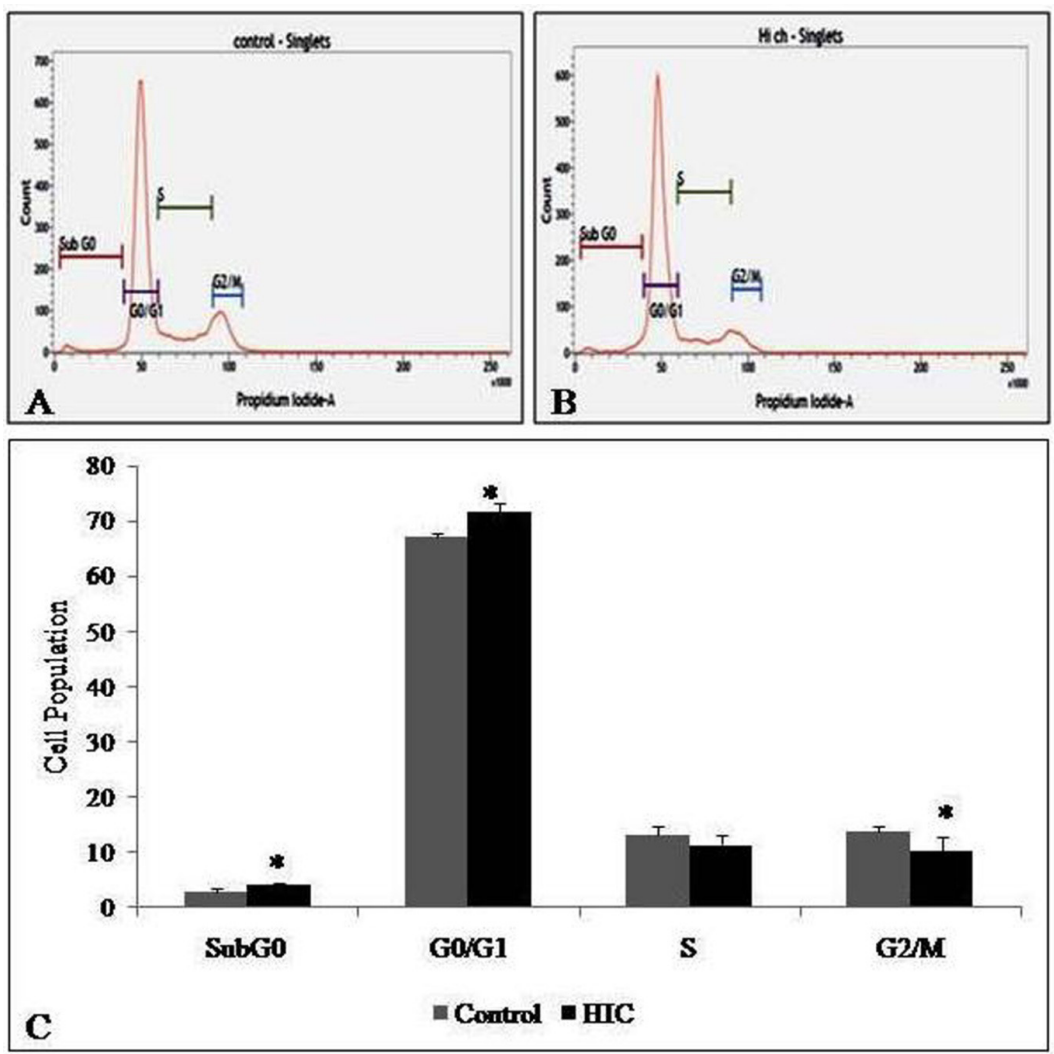

Fig. 8: Representative histograms [A) Control, B) HIC] along with Bar graph [C] showing cell distribution in different phases in sets of SiHa cells; columns represent the cell populations while bars represent standard deviations. * denotes significant difference between control and treated sets $(\mathrm{P}<0.05)[\mathrm{T}-\mathrm{Test}-\mathrm{GraphPad}$ Prism5].
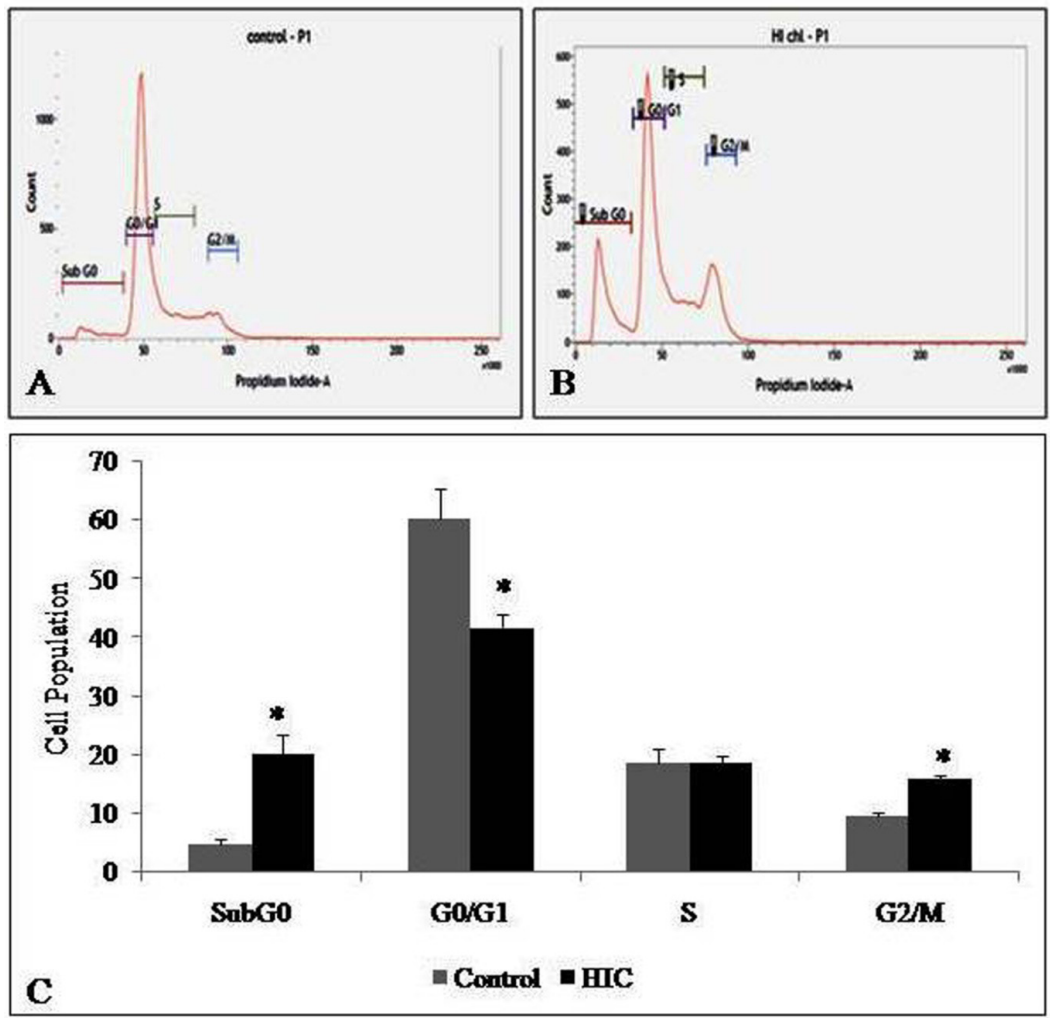

Fig. 9: Representative histograms [A) Control, B) HIC] along with Bar graph [C] showing cell distribution in different phases in sets of C33A cells; columns represent the cell populations while bars represent standard deviations. * denotes significant difference between control and treated sets $(\mathrm{P}<0.05)[\mathrm{T}-\mathrm{Test}-\mathrm{GraphPad}$ Prism5]. 


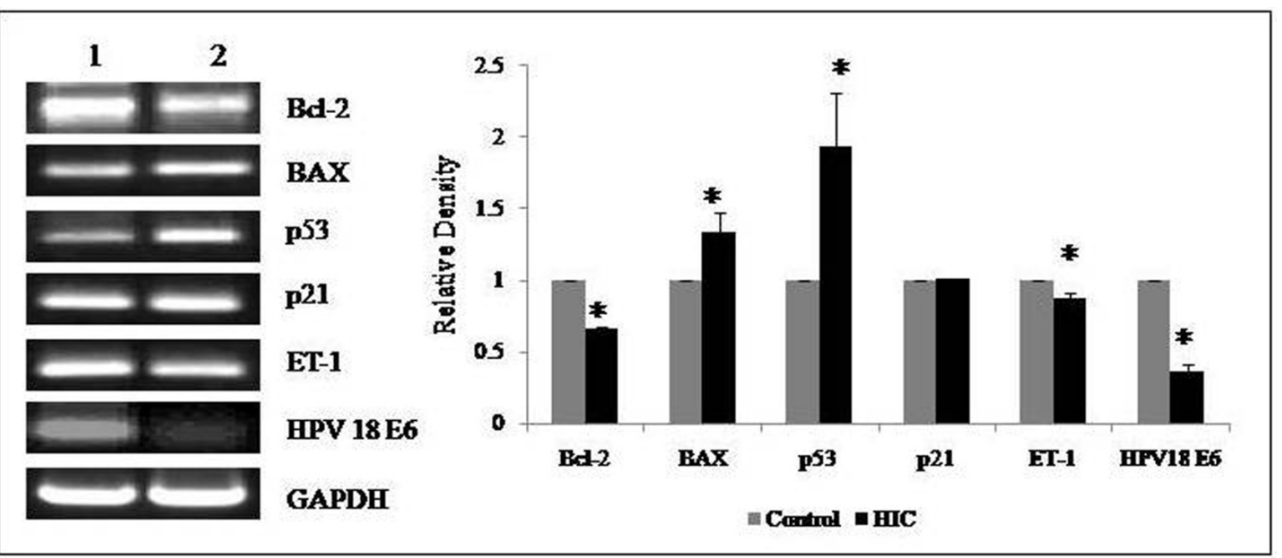

Fig. 10: Representative PCR expressions of several genes in control and treated sets in HeLa cells [1: Control set, 2: HIC treated] along with densitometric analysis, columns represent the relative densities while bars represent standard deviations. * denotes significant difference between control and treated sets $(\mathrm{P}<0.05)[\mathrm{T}-\mathrm{Test}-$ GraphPad Prism5].

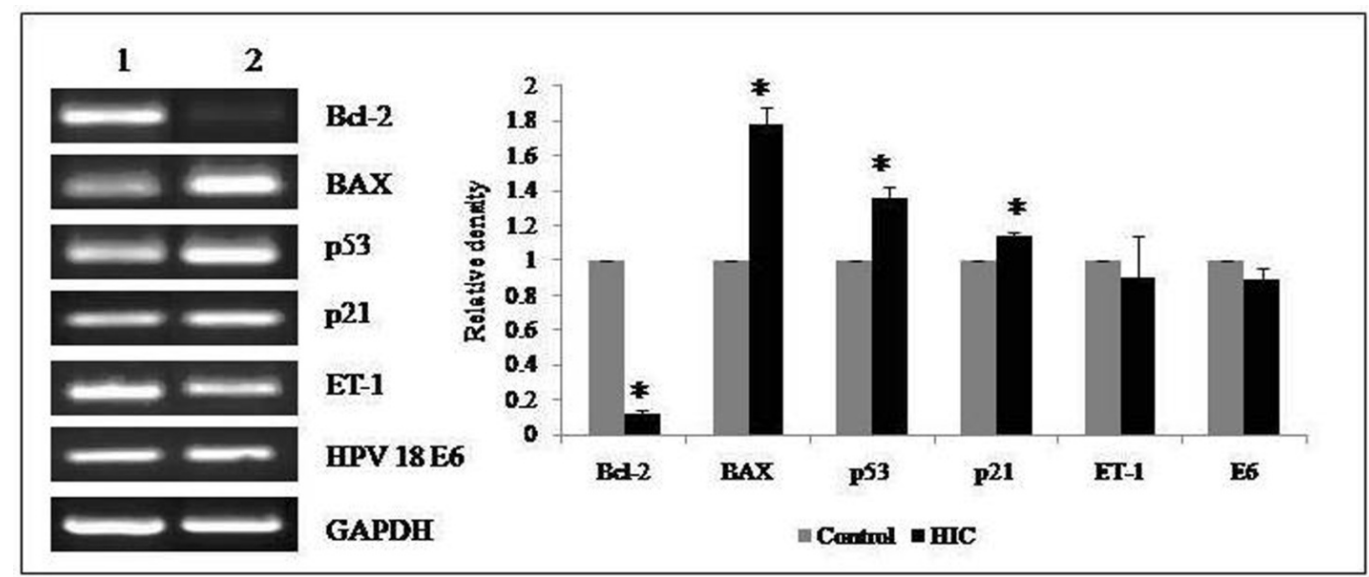

Fig. 11: Representative PCR expressions of several genes in control and treated sets in SiHa cells [1: Control set, 2: HIC treated] along with densitometric analysis, columns represent the relative densities while bars represent standard deviations. * denotes significant difference between control and treated sets $(\mathrm{P}<0.05)[\mathrm{T}-\mathrm{Test}-$ GraphPad Prism5].

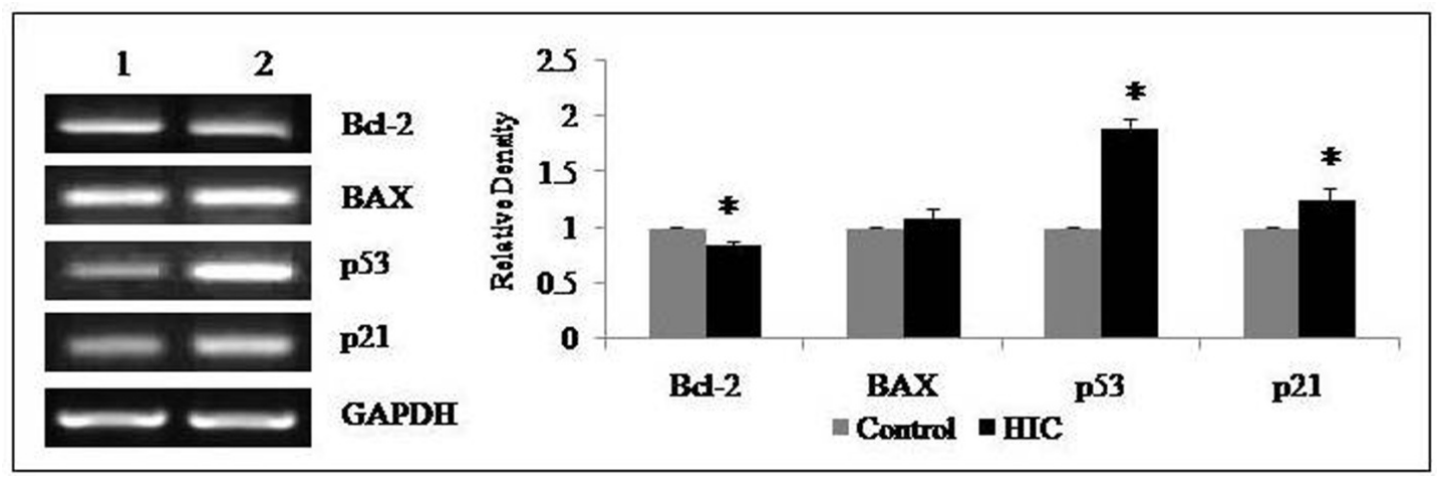

Fig. 12: Representative PCR expressions of several genes in control and treated sets in C33A cells [1: Control set, 2: HIC treated] along with densitometric analysis, columns represent the relative densities while bars represent standard deviations. * denotes significant difference between control and treated sets $(\mathrm{P}<0.05)[\mathrm{T}-\mathrm{Test}-$ GraphPad Prism5].

\section{Protein expression study}

In all the cell lines, treated cells showed an increase in expressions of effecter Caspase-3, pro-apoptotic BAX, p53, p21 and decrease in anti-apoptotic Bcl-2, HPV 16/18 E6 proteins.
In HeLa cells, Bcl-2 expression was reduced by 0.21 fold while HPV 18 E6 was reduced by 0.73 fold. Expressions of cleaved caspase-3, BAX, p53, p21 were increased by 5.017 fold, 1.51 fold, 1.03 fold and 1.84 fold respectively (Figure 13). In SiHa cells, 
cleaved caspase-3 expression was increased by 1.64 fold while those for BAX, p53, and p21 were increased by 1.5 fold, 1.52 fold and, 1.47 fold respectively. Expressions of Bcl-2 and HPV 16 E6 were decreased by 0.17 fold and 0.62 fold respectively (Figure
14). C33A cells showed an increase of 6.31 fold for cleaved caspase-3, 2.06 fold for BAX, 1.25 fold for p53 and 3.65 fold for p21. Expression of Bcl-2 had decreased by 0.18 fold (Figure 15).

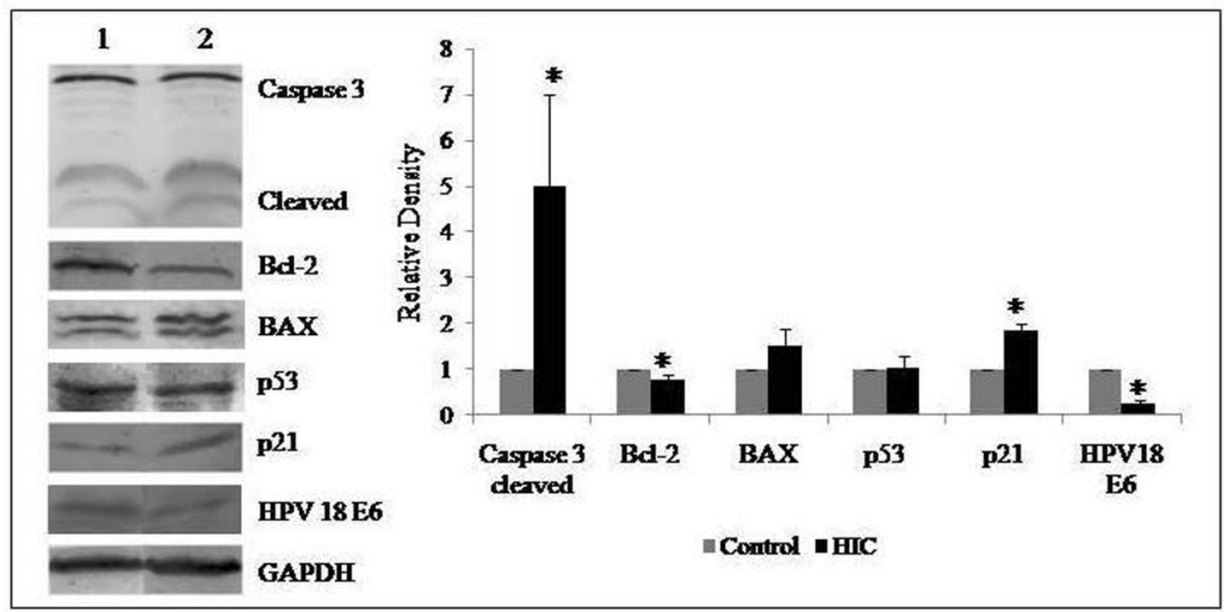

Fig. 13: Representative western blots of several genes in control and treated sets in HeLa cells [1: Control set, 2: HIC treated] along with densitometric analysis, columns represent the relative densities while bars represent standard deviations. * denotes significant difference between control and treated sets $(\mathrm{P}<0.05)[\mathrm{T}-\mathrm{Test}-$ GraphPad Prism5].

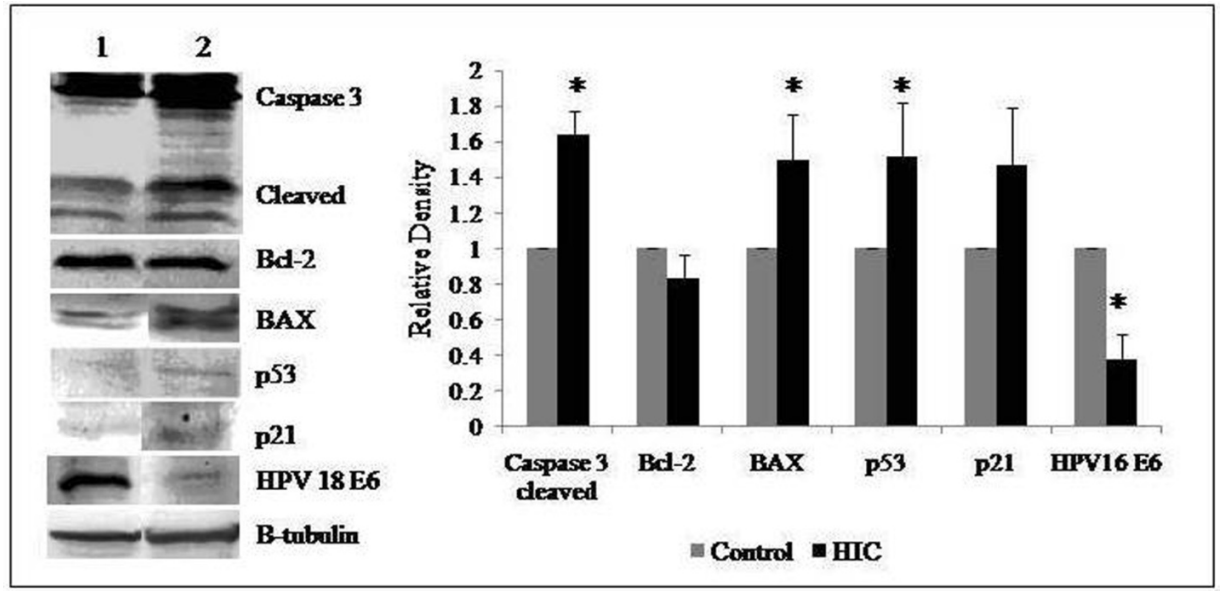

Fig. 14: Representative western blots of several genes in control and treated sets in SiHa cells [1: Control set, 2: HIC treated] along with densitometric analysis, columns represent the relative densities while bars represent standard deviations. $*$ denotes significant difference between control and treated sets $(\mathrm{P}<0.05)[\mathrm{T}-\mathrm{Test}-\mathrm{GraphPad}$ Prism5].

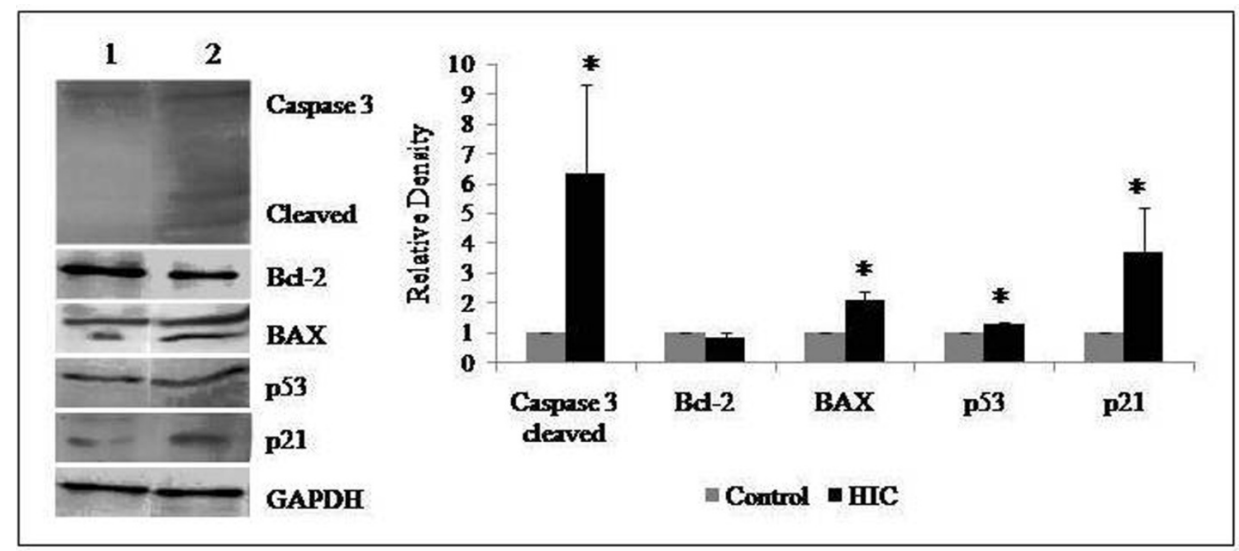

Fig. 15: Representative western blots of several genes in control and treated sets in C33A cells [1: Control set, 2: HIC treated] along with densitometric analysis, columns represent the relative densities while bars represent standard deviations. * denotes significant difference between control and treated sets $(\mathrm{P}<0.05)[\mathrm{T}-\mathrm{Test}-$ GraphPad Prism5]. 


\section{ROS generation by HIC treatment}

In presence of ROS, $\mathrm{H}_{2}$ DCFDA get converted to fluorescent DCF which fluoresce green. In the untreated cells, no fluorescence of DCF was recorded. In the treated sets, high amount of DCF was detected in all the cell lines (Figures 16, 17, and 18 ). $84.27 \%, 83.27 \%$, and $81.98 \%$ cells were found positive with ROS production.
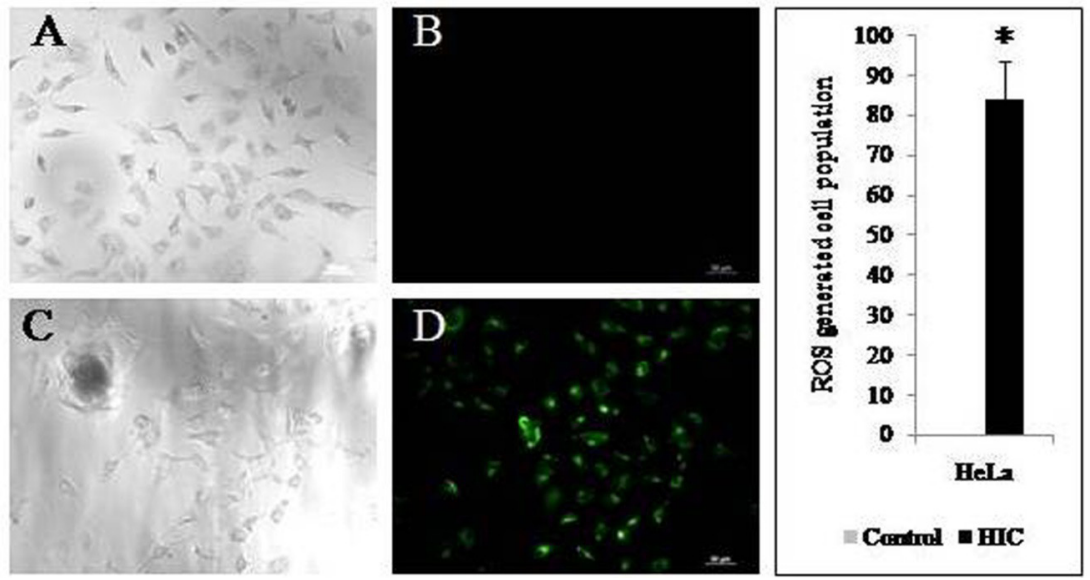

Fig. 16: ROS formation in HeLa cells. Green fluorescence showed the presence of DCF. Scale represents $50 \mu \mathrm{m}$. A \& B: Control cells, C \& D: Treated cells along with bar diagram showing ROS generated cell population. Columns represent the cell populations while bars represent standard deviations. * denotes significant difference between control and treated sets $(\mathrm{P}<0.05)$ [T-Test-GraphPad Prism5].
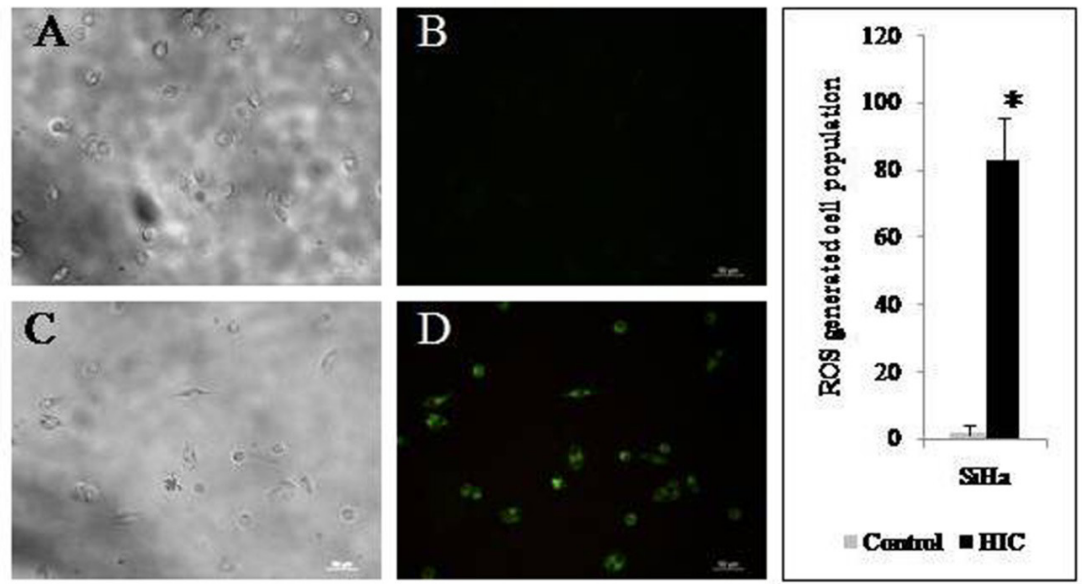

Fig. 17: ROS formation in SiHa cells. Green fluorescence showed the presence of DCF. Scale represents $50 \mu \mathrm{m}$. A \& B: Control cells, C \& D: Treated cells along with bar diagram showing ROS generated cell population. Columns represent the cell populations while bars represent standard deviations. * denotes significant difference between control and treated sets $(\mathrm{P}<0.05)$ [T-Test-GraphPad Prism5].
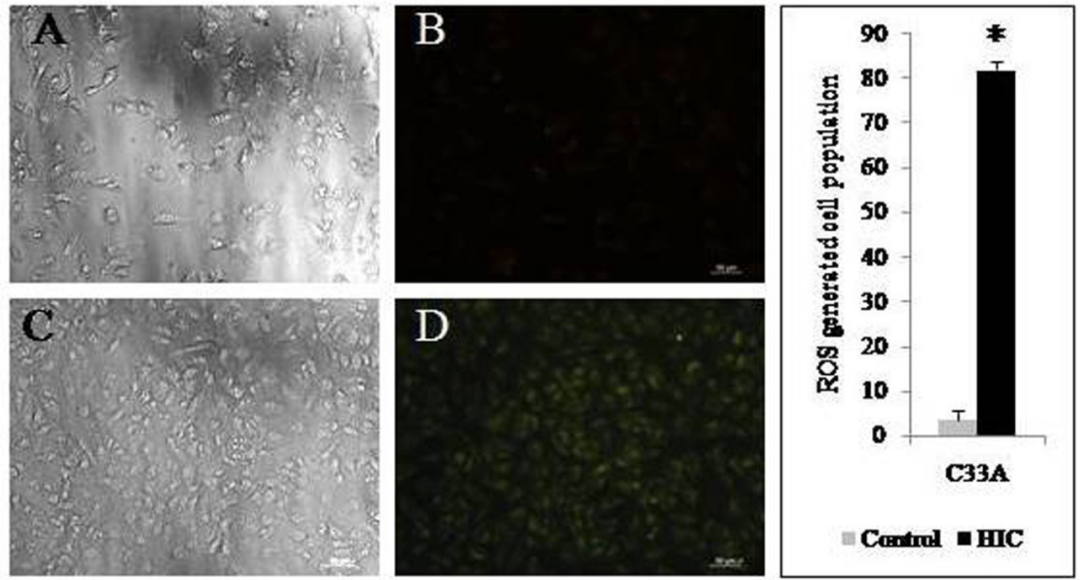

Fig. 18: ROS formation in C33A cells. Green fluorescence showed the presence of DCF. Scale represents $50 \mu \mathrm{m}$. A \& B: Control cells, C \& D: Treated cells along with bar diagram showing ROS generated cell population. Columns represent the cell populations while bars represent standard deviations. * denotes significant difference between control and treated sets $(\mathrm{P}<0.05)$ [T-Test-GraphPad Prism5]. 


\section{MMP loss by HIC treatment}

Formation of ROS can cause loss of mitochondrial membrane potential. JC1 in aggregated form fluoresce red while the monomers fluoresce green in depolarized cells. In the treated cells, green fluorescence increased largely. HeLa, SiHa and C33A cells showed $70.01 \%, 79.54 \%$ and $87.76 \%$ depolarized cells (Figures 19, 20, and 21).
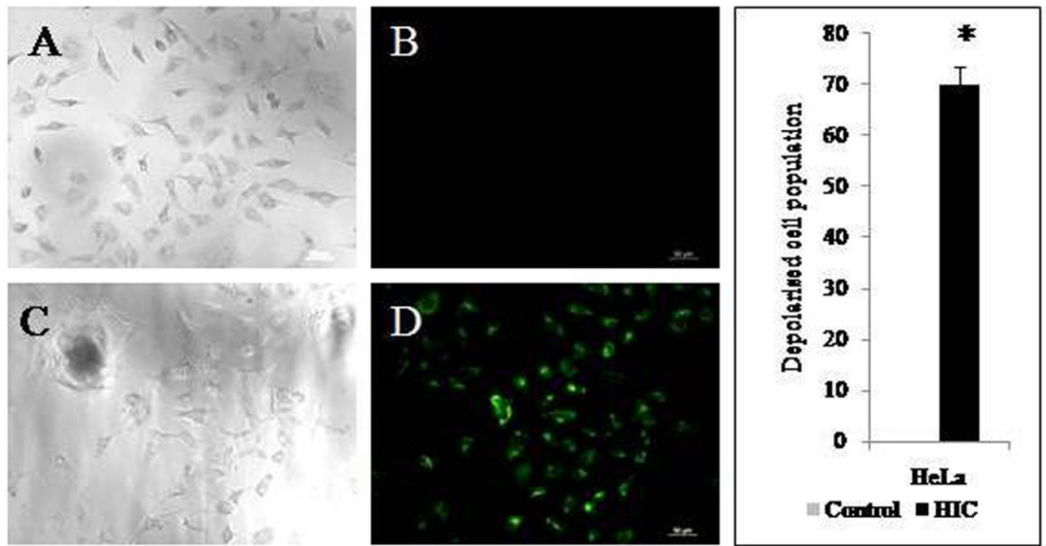

Fig. 19: Loss of MMP in HeLa cells. Green fluorescence showed the presence of JC1 monomers in depolarized cells. Scale represents $50 \mu \mathrm{m}$. A \& B: Control cells, C \& D: Treated cells along with bar diagram showing depolarized cell population. Columns represent the cell populations while bars represent standard deviations. * denotes significant difference between control and treated sets $(\mathrm{P}<0.05)$ [T-Test-GraphPad Prism5].
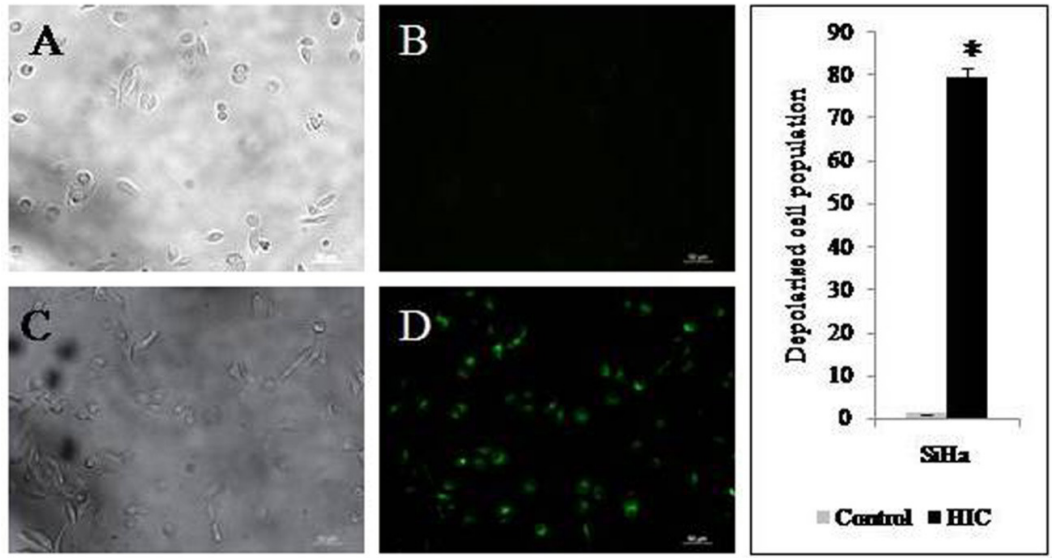

Fig. 20: Loss of MMP in SiHa cells. Green fluorescence showed the presence of JC1 monomers in depolarized cells. Scale represents $50 \mu \mathrm{m}$. A \& B: Control cells, C \& D: Treated cells along with bar diagram showing depolarized cell population. Columns represent the cell populations while bars represent standard deviations. $*$ denotes significant difference between control and treated sets $(\mathrm{P}<0.05)$ [T-Test-GraphPad Prism5].
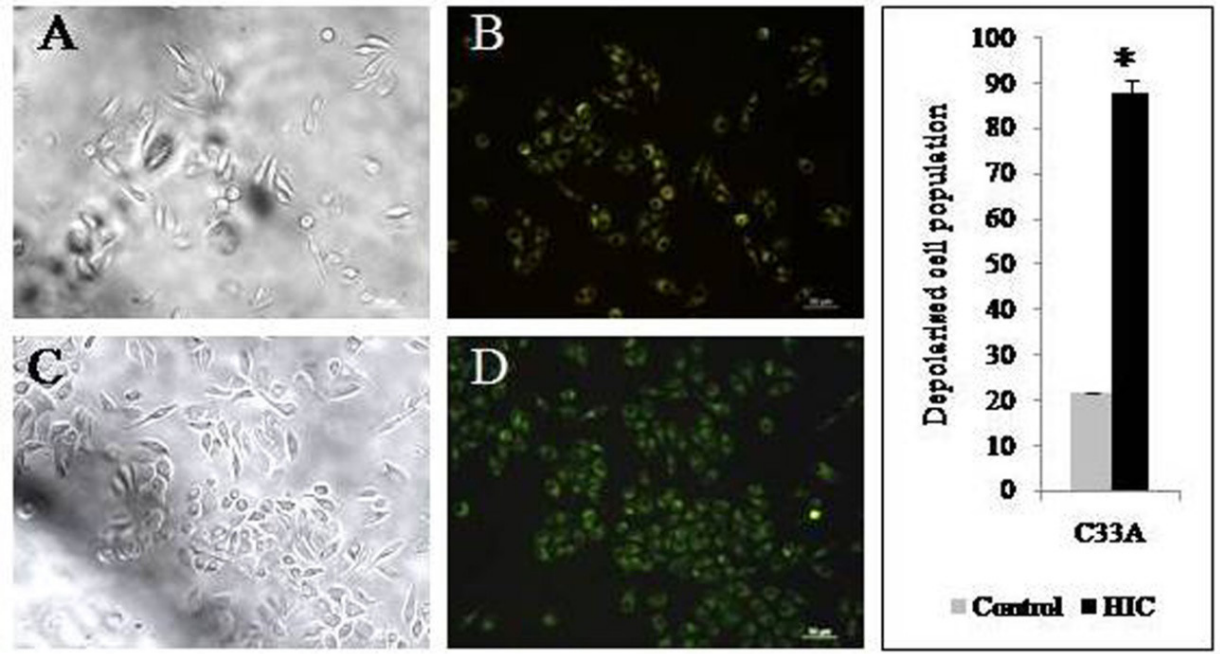

Fig. 21: Loss of MMP in C33A cells. Green fluorescence showed the presence of JC1 monomers in depolarized cells. Scale represents $50 \mu \mathrm{m}$. A \& B: Control cells, C \& D: Treated cells along with bar diagram showing depolarized cell population. Columns represent the cell populations while bars represent standard deviations. * denotes significant difference between control and treated sets $(\mathrm{P}<0.05)$ [T-Test-GraphPad Prism5]. 
ROS mediated DNA damage

Incorporation of $\gamma H 2 A X$

For all the three cell lines, treated sets showed the presence of $\gamma$-H2AX which is a marker of DNA damage. At 6 hours time point this incorporation of phospho variant of $\mathrm{H} 2 \mathrm{AX}$ clearly indicated DNA damage which might be the cause for the induction of apoptosis in the treated sets (Figures 22, 23, and 24).

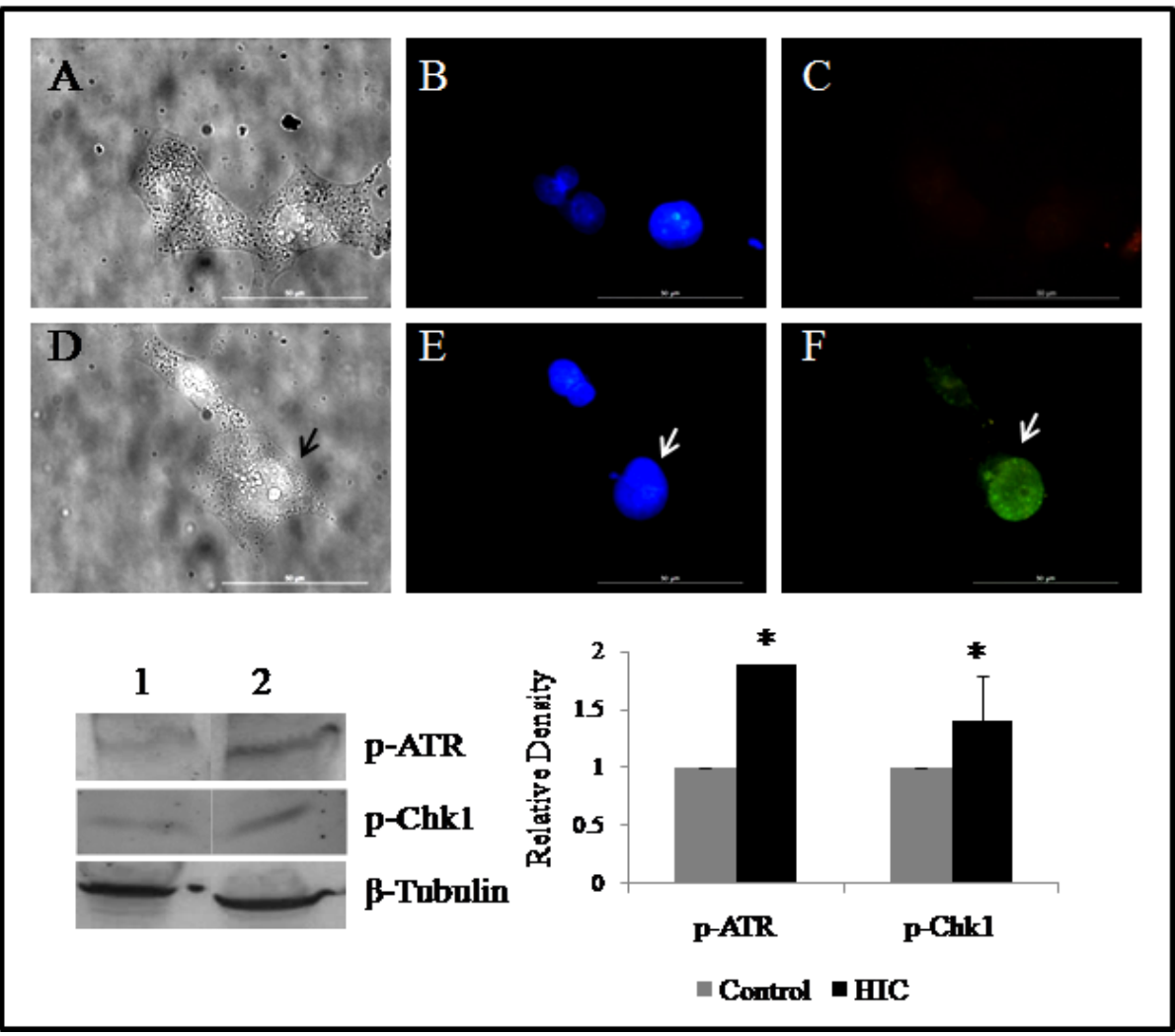

Fig. 22: DNA damage responses in HeLa cells. $\gamma \mathrm{H} 2 \mathrm{AX}$ incorporation [A, B \& C: Phase, Hoechst 33258 and $\gamma \mathrm{H} 2 \mathrm{AX}-\mathrm{FITC}$ in control cells; D, E, and F: Phase, Hoechst 33258 and $\gamma$ H2AX-FITC in treated cells. Representative western blots of several genes in control and treated sets [1: Control set, 2: HIC treated] along with densitometric analysis, columns represent the relative densities while bars represent standard deviations. * denotes significant difference between control and treated sets $(\mathrm{P}<0.05)$ [T-Test-GraphPad Prism5].

\section{Western blot of DNA damage responsive proteins}

Expression of key regulators of DNA damage pathways was checked. In all the cell lines expressions of p-ATM and p-Chk2 were not detected. But expressions of p-ATR and p-Chk1 were detected suggesting the involvement of single-strand DNA breaks. In HeLa cells, p-ATR and p-Chk1 expression increased by 1.88 fold and 1.41 fold respectively (Figure 22). While 2.21 fold and 1.95 fold increase in p-ATR and p-Chk1 expression were found in SiHa cells (Figure 23). Same types of responses were also seen in C33A cells, with an increase of 2.96 fold and 1.56 fold for p-ATR and p-Chk1 respectively (Figure 24).

\section{GC-MS}

GC-MS data analysis showed the presence of phenolic compounds as well as terpenoids especially Squalene. Squalene is considered to acts as the precursor for steroid biosynthesis. Major peaks were summarized in Table 3. Figure 25 showed the GC-MS chromatogram.

\section{LC-MS}

LC-MS data analysis showed the presence of phenolic compounds as well as alkaloids. Major peaks were summarized in Table 4. Figure 26 showed the LC-MS chromatogram.

\section{Column chromatography \& GC-MS}

From the HIC fraction, around 25 subfractions were isolated by silica gel chromatography. Out of them, several subfractions $(6,7,8,9$ and 10) were found to be cytotoxic (assessed by MTT assay). They were analyzed by GC-MS and several common phytochemicals were identified with NIST library. Common constituents of the HIC subfractions were Palmitic acid TMS ester, Stearic acid TMS ester, Linoleic acid TMS ester etc. SF 6 had 31.2\% Palmitic acid TMS ester, 11.6\%, Linoleic acid TMS ester, 8.7\% Oleic acid TMS ester, 37.6\% Stearic acid TMS ester. SF 7 had 1.1\% Benzoic acid TMS ester, 0.9\% Phenol2,4bis (1,1-dimethylethyl), 22.7\% Palmitic acid TMS ester, $1.06 \%$ Linoleic acid TMS ester, $13.5 \%$ Stearic acid TMS ester. SF8 had $1.68 \%$ Benzoic acid TMS ester, 24.2\% Palmitic acid TMS ester, $34.6 \%$ Stearic acid TMS ester. SF 9 had $1.21 \%$ Benzenacetic acid TMS ester, 4.8\% Benzoic acid TMS ester, 26.2\% Palmitic acid TMS ester, $37.17 \%$ Stearic acid TMS ester. SF 10 had $5.08 \%$ Azelaic acid-bis TMS ester, 36.17\% Palmitic acid TMS ester, $44.08 \%$ Stearic acid TMS ester. 


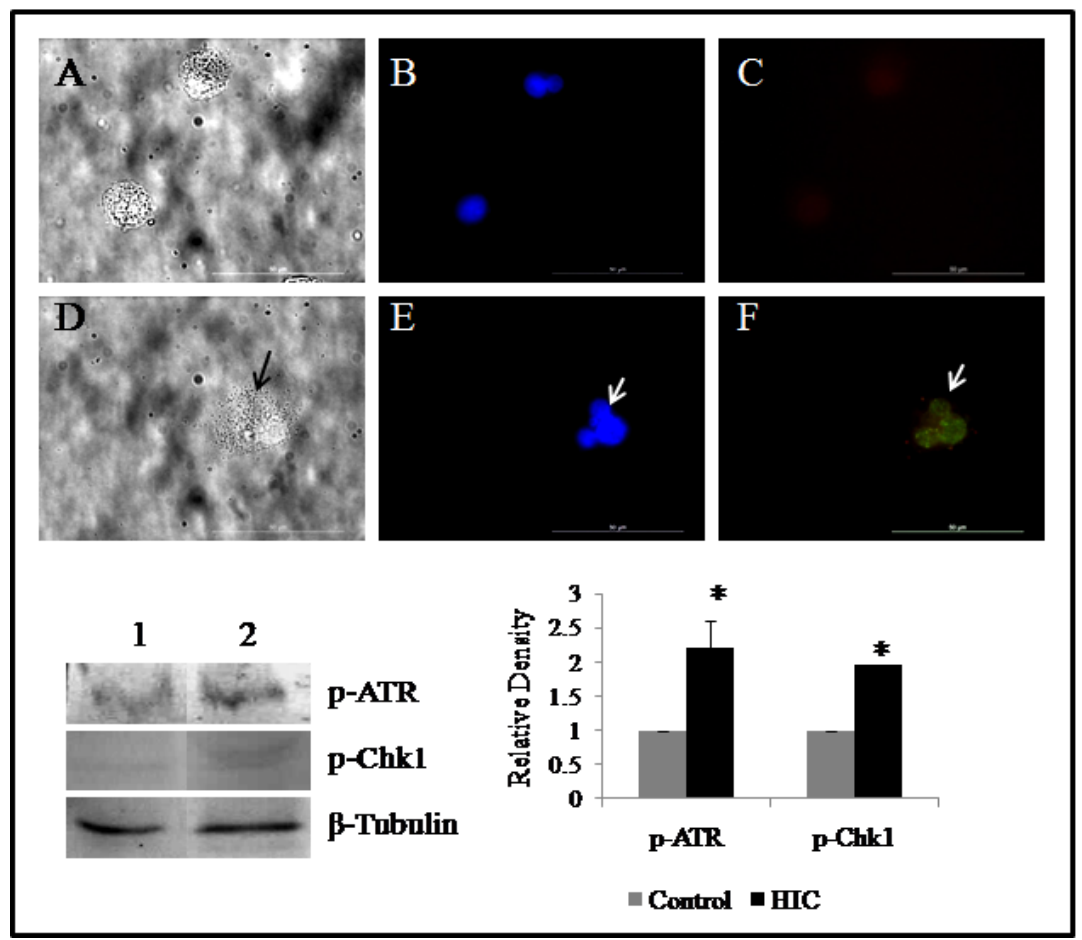

Fig. 23: DNA damage responses in SiHa cells. $\gamma \mathrm{H} 2 \mathrm{AX}$ incorporation [A, B \& C: Phase, Hoechst 33258 and $\gamma \mathrm{H} 2 \mathrm{AX}$-FITC in control cells; D, E, and F: Phase, Hoechst 33258 and $\gamma \mathrm{H} 2 \mathrm{AX}$-FITC in treated cells. Representative western blots of several genes in control and treated sets [1: Control set, 2: HIC treated] along with densitometric analysis, columns represent the relative densities while bars represent standard deviations. ${ }^{*}$ denotes significant difference between control and treated sets $(\mathrm{P}<0.05)$ [T-Test-GraphPad Prism5].

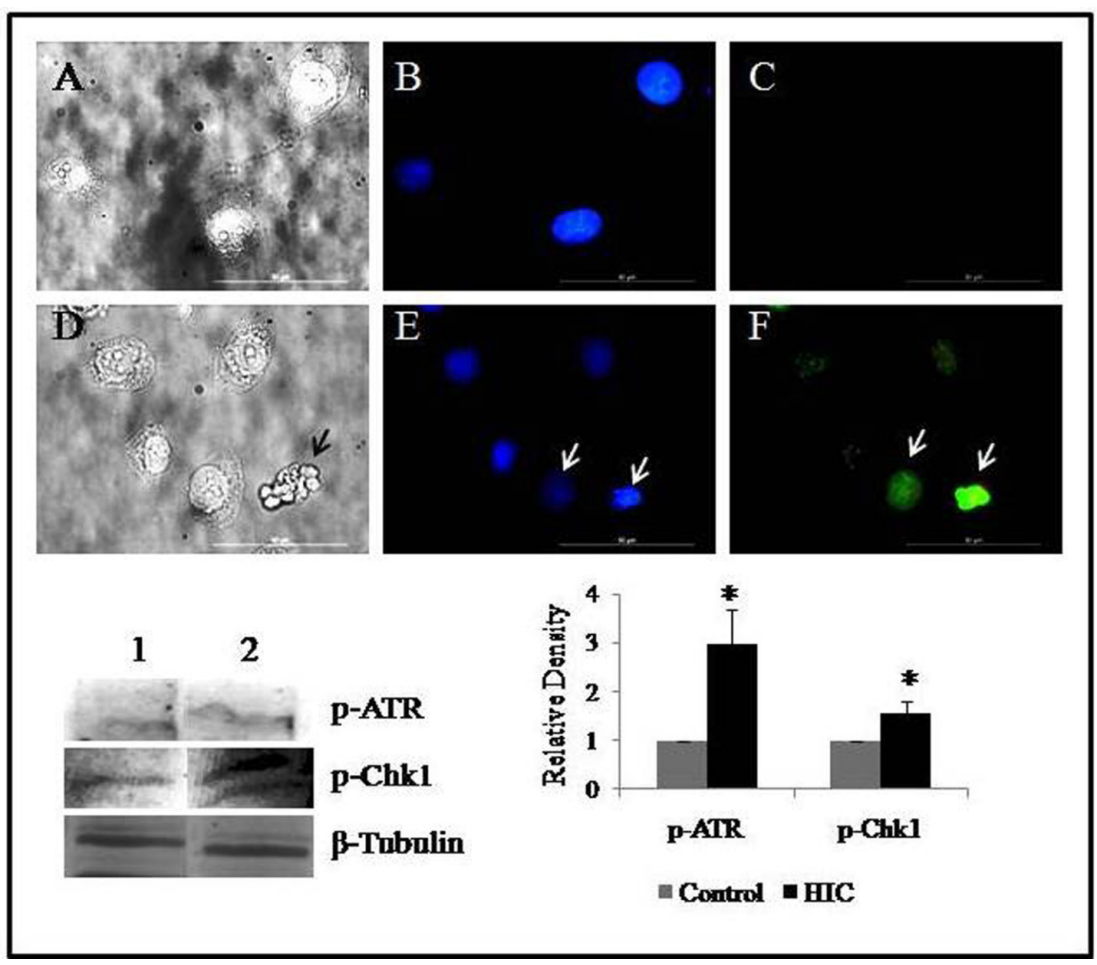

Fig. 24: DNA damage responses in C33A cells. $\gamma$-H2AX incorporation [A, B \& C: Phase, Hoechst 33258 and $\gamma \mathrm{H} 2 \mathrm{AX}-\mathrm{FITC}$ in control cells; D, E, and F: Phase, Hoechst 33258 and $\gamma \mathrm{H} 2 \mathrm{AX}$-FITC in treated cells. Representative western blots of several genes in control and treated sets [1: Control set, 2: HIC treated] along with densitometric analysis, columns represent the relative densities while bars represent standard deviations. * denotes significant difference between control and treated sets $(\mathrm{P}<0.05)[\mathrm{T}-$ Test-GraphPad Prism5]. 
Table 3: GC-MS analysis of $H$. indicum chloroform fraction (HIC).

\begin{tabular}{ccc}
\hline RT & Area \% & Probable compound \\
\hline 18.15 & 22.618 & Phenol-2,4-bis-1,1-dimethylethyl \\
19.951 & 4.065 & Cetane \\
24.330 & 7.274 & E-15 Heptadecanal \\
25.963 & 1.015 & Phthalic acid hex-3-yl isobutyl ester \\
26.888 & 2.336 & 1,2-Benzen dicarboxylic acid butyl ester \\
27.808 & 4.075 & Dibutylphthalate \\
28.208 & 2.764 & Phthalic acid butyl hex-3-yl ester \\
28.321 & 7.505 & 5-Icosene \\
29.622 & 1.068 & Phthalic acid butyl-8-chlorooctylester \\
31.961 & 5.752 & Cycloeicosene \\
34.914 & 2.227 & 1,3,4,5,6-tetra-tert-butylbiphenyldiol \\
35.307 & 2.909 & 1-Heniocosanol \\
37.773 & 8.654 & Phthalic acid, di (2-propylpentyl) ester \\
42.477 & 8.384 & Squalene \\
\hline
\end{tabular}

\section{DISCUSSION}

The increased population of Annexin V-FITC stained cells clearly showed induction of apoptotic cell death in the treated cells. A significant increase in the early and late apoptotic population was found in the treated cells of all cell lines. HIC treatment induced rise in sub G0 populations in HeLa and C33A cell lines indicated cytotoxicity. It also induced $\mathrm{G} 1 / \mathrm{S}$ cell cycle block in the treated $\mathrm{SiHa}$ cells. In this study, it was observed, that p21 played a role in arresting the cells in G1/S. p53 acted as a master switch which might have regulated the cell death pathway. In the present study, decreased expression of HPV 16/18 E6 was observed in the treated cells (HeLa and $\mathrm{SiHa}$ ). That might have stabilized the p53 protein and also aid in p21 up-regulation. Reduced expression of autocrine signaling growth factor ET-1 also helped in reducing cell proliferation and growth of HPV containing HeLa and SiHa cells. Increased expression of cleaved caspase-3, Bax, p53, p21 and decreased expression of $\mathrm{Bcl}-2$ suggested the involvement of apoptosis in cell death. In-vitro cytotoxicity is often associated with DNA damage. DNA damage increases p53 expression, which induces p21 transcription which in turn leading to cell cycle arrest at G1 or G2 (Jimeno et al., 2008). HIC treatment at $3 \mathrm{~h}$ duration had induced ROS generation in treated cells with loss of membrane potential leading to severe DNA damage and induced DNA damage responsive pathways. Incorporation of $\gamma \mathrm{H} 2 \mathrm{AX}$ and expressions of p-ATR and p-Chk1 validated the hypothesis. Extensive DNA damage affects mitochondria, inducing the release of cytochrome $\mathrm{c}$ leading to caspase activation and apoptosis. The mode of action of HIC treatment was depicted by the hypothetical diagram Figure 27.

GC-MS and LC-MS analysis of HIC fraction had suggested the presence of several characteristic phytochemicals like alkaloids, phenols, terpenoids, fatty acids etc. Indicine $\mathrm{N}$-oxide, heliotrine were the characteristic finds. Rutin, catechin, methoxycinnamic acid, squalene, phenol-2,4 bis (1,1-dimethylethyl) etc. were also present. Both short chained (C4-Butanedioic acid, C-7Benzoic acid) and long chained (C18-Stearic acid, Oleic acid, Linoleic acid) fatty acids were detected. Several unsaturated fatty acids are reported to have anticancer activities (Chapkin et al.,
2007; Lee et al., 2008; Sakai et al., 2012; Tsuzuki, 2007). Phenol 2,4-Bis (1,1-dimethyl ethyl) found in HIC was also detected in the bioactive (ethanolic acid) fraction of $S$. trilobatum inhibiting Elrich's Ascites Carcinoma growth (Xavier et al., 2013). Stearic acid reported having inhibitory activity against cervical cancer line HOG-1 (Gleeson et al., 1990) also present in the HIC fraction. Palmitic acid showed selective cytotoxicity to MOLT-4 (Human leukemic) cell line, probably by inhibiting DNA topoisomerase I (Harada et al., 2002) had been found in this fraction. Linoleic acid present in HIC was found to have inhibitory activity against rat hepatoma (AH-109A) cell line (Hayashi et al., 1990). Oleic acid detected in HIC had inhibited cell growth in different tumor cell lines in a calcium signaling-dependent manner (Carrillo et al., 2012). Different benzoic acid derivatives such as benzoic acid 4methoxy 3 (TMS) oxy, benzene acetic acid, benzoic acid was also detected in HIC. Azelaic acid was found to have selective cytotoxicity towards melanoma cells (Lemic-Stojcevic et al., 1995).

Table 4: LC-MS/MS analysis of $H$. indicum chloroform fraction (HIC).

\begin{tabular}{ccc}
\hline RT $($ Min) & Probable compound & Method \\
\hline 0.95 & Indicine N-Oxide & Mono isotopic mass \\
1.46 & Heliotrine & Mono isotopic mass \\
2.02 & Rapanone & ReSpect database \\
2.32 & Indicine & Mono isotopic mass \\
3.29 & 3-methoxy cinnamic acid & MZ cloud database \\
5.53 & Rutin & MZ cloud database \\
6.59 & Catechin & MZ cloud database \\
7.25 & $\alpha$-Eleostearic acid & MZ cloud database \\
8.73 & Stearic acid & MZ cloud database \\
9.59 & Diethyl phthalate & MZ cloud database \\
\hline
\end{tabular}

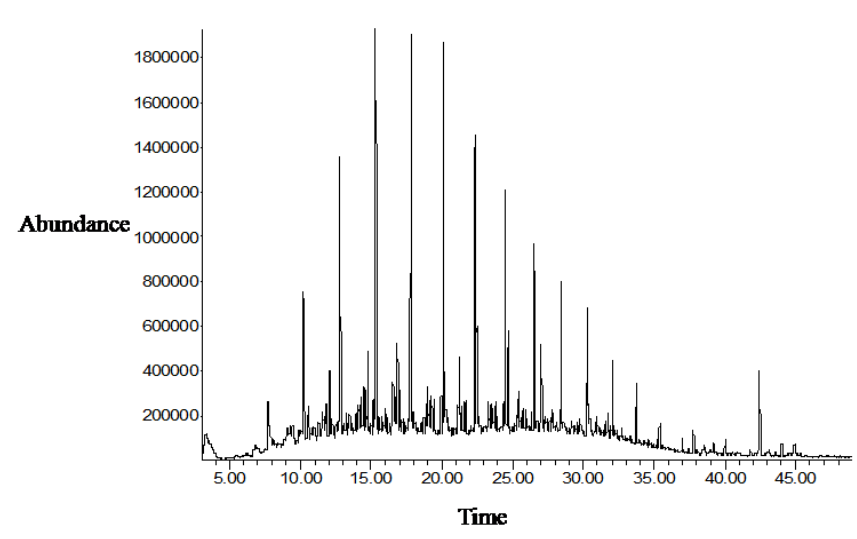

Fig. 25: GC-MS chromatogram of Heliotropium indicum chloroform fraction (HIC).

\section{CONCLUSION}

From the study, it can be concluded that the HIC fraction was capable of inducing apoptosis in cervical cancer cells. Induction of ROS mediated DNA damage might have induced cell death in the cancer cells. Presence of single strand damaged DNA was detected in the treated cells. Induction of ATR activation pathway has vindicated the hypothesis. The HIC fraction was rich in different cytotoxic fatty acid, phenolic substances, and characteristic alkaloids. So this fraction of Heliotropium indicum 
plant may serve as a repertoire of several anticancer lead molecules for future use.

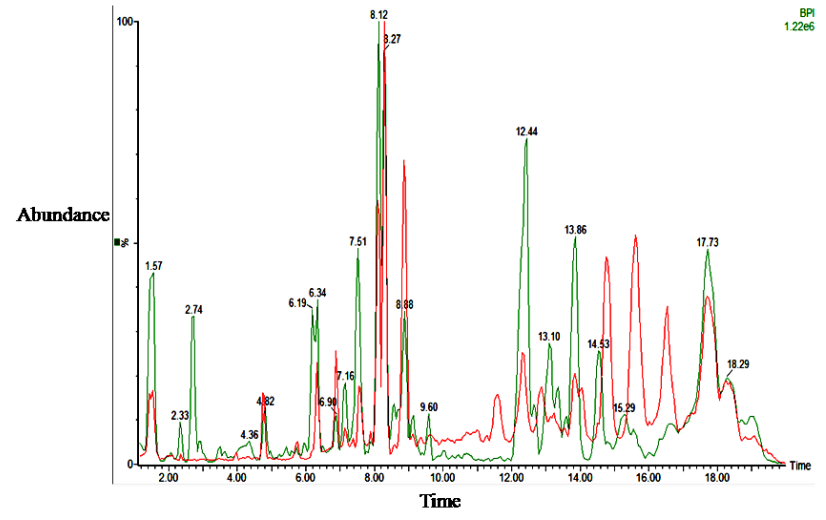

Fig. 26: LC-MS chromatogram of Heliotropium indicum chloroform fraction (HIC). Green and red lines correspond to low and high energy chromatograms respectively.

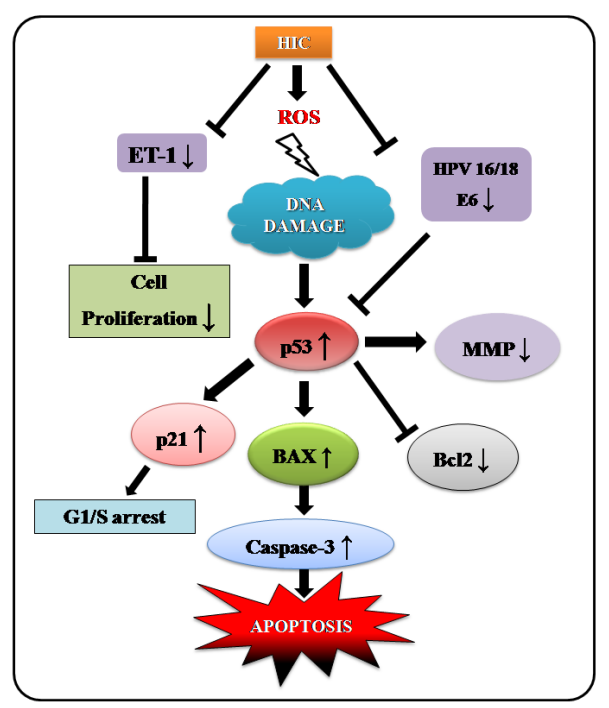

Fig. 27: Hypothetical diagram showing the mode of action of the HIC fraction on the cervical cancer cells.

\section{ACKNOWLEDGMENT}

Authors would like to thank UGC-CAS, DST-FIST, DST-PURSE, Department of Botany and CRNN, the University of Calcutta for instrumentation and infrastructural support. WB-DBT is acknowledged for funding this study [595-BT(Esst)/ RD-2/11]. SP would like to thank UGC, GOI for the award of research fellowships. Authors are very thankful to Dr. K. P. Dhara and Mr. D. Patra for their help in column chromatography works.

\section{CONFLICT OF INTERESTS}

The authors declare no conflicts of interest.

\section{REFERENCES}

Aranda PS, LaJoie DM, Jorcyk CL. Bleach Gel: A Simple Agarose Gel for Analyzing RNA Quality. Electrophoresis, 2012; 33(2):366369 .

Carrillo C, Cavia M, Alonso-Torre SR. Antitumor effect of oleic acid; mechanisms of action. A review. Nutricion hospitalaria, 2012;
27(6):1860-5

Chapkin RS, McMurray DN, Lupton JR. Colon cancer, fatty acids and anti-inflammatory compounds, 2007; 23(1):48-54.

Dash GK, Abdullah MS. A review on Heliotropium indicum L. (Boraginaceae). IJPSR, 2013; 4(4):1253-1258.

Duttagupta S, Dutta PC. Pharmacognostic study of the leaf of Heliotropium indicum. J Crude Drug Res, 1977; 15:141.

Gleeson RP, Ayub M, Wright JT, Wood CB, Habib NA, Soutter WP, et al. Fatty acid control of growth of human cervical and endometrial cancer cells. British journal of cancer, 1990; 61(4):500.

Harada H, Yamashita U, Kurihara H, Fukushi E, Kawabata J, Kamei Y. Antitumor activity of palmitic acid found as a selective cytotoxic substance in a marine red alga. Anticancer research, 2002; 22(5):2587-2590.

Hayashi Y, Fukushima S, Hirata T, Kishimoto S, Katsuki T, Nakano M. Anticancer Activity of Free $\gamma$-Linolenic Acid on AH-109A Rat Hepatoma Cells and the Effect of Serum Albumin on Anticancer Activity of $\gamma$-Linolenic Acid in Vitro. Journal of pharmacobio-dynamics, 1990; 13(11):705-711.

Jimeno A, Rudek MA, Kulesza P, Ma WW, Wheelhouse $\mathrm{J}$, Howard A, et al. Pharmacodynamic-guided modified continuous reassessment method-based, dose-finding study of rapamycin in adult patients with solid tumors. Journal of clinical oncology, 2008; 26(25):41724179.

Karra N. Rajanighantu-An important lexicon of preBhavaprakasha era. Ann Ayurvedic Med, 2013; 2(3):104-108.

Lee J, Hwang DH. 2008. Dietary fatty acids and eicosanoids. In: Chow CK, editor. Fatty acids in foods and their Heath Implecations. London, UK: CRC Press 713-39.

Lemic-Stojcevic L, Nias AHW, Breathnach AS. Effect of azelaic acid on melanoma cells in culture. Experimental dermatology, 1995; $4(2): 79-81$.

Oluwatoyin SM, Illeogbulam NG, Joseph A. Phytochemical and antimicrobial studies on the aerial parts of Heliotropium indicum Linn. Annals of Biological Research, 2011; 2(2):129-136.

Paul S, Chakraborty S, Mukherjee A, Kundu R. Evaluation of cytotoxicity and DNA damaging activity of three plant extracts on cervical cancer cell lines. Int J Pharm Sci Rev Res, 2015; 31(1):183-189.

Reddy JS, Rao PR, Reddy Mada S. Wound healing effects of Heliotropium indicum, Plumbago zeylanicum and Acalypha indica inrats. Journal of ethnopharmacology, 2002; 79:249-251.

Roeder E, Wiedenfeld H. Pyrrolizidine alkaloids in plants used in the traditional medicine of Madagascar and the Mascarene islands. Pharmazie, 2011; 66:637-647.

Sakai M, Kakutani S, Horikawa C, Tokuda H, Kawashima H, Shibata $\mathrm{H}$, et al. Arachidonic acid and cancer risk: a systematic review of observational studies. BMC cancer, 2012; 12(1):606.

Togola A, Diallo D, Dembele S, Barsett H, Paulsen BS. Ethnopharmacological survey of different uses of seven medicinal plants from Mali, (West Africa) in the regions Doila, Kolokani and Siby. Journal of Ethnobiology and Ethnomedicine, 2005; 1:7.

Tsuzuki T, Shibata A, Kawakami Y, Nakagawa K, Miyazawa T. Conjugated eicosapentaenoic acid inhibits vascular endothelial growth factor-induced angiogenesis by suppressing the migration of human umbilical vein endothelial cells. The Journal of nutrition, 2007; 137(3):641646.

Xavier AP, Santharam L, Panigrahi S, Muthuraman MS, Pemiah B. Antitumor potential of ethanolic extract of Solanum trilobatum against Ehrlich's Ascites Carcinoma. International Journal of Pharm Tech Research, 2013; 5(3):1119-1125.

How to cite this article:

Paul S, Kundu R. ROS mediated DNA damage and induction of apoptosis in cervical cancer cells by Heliotropium indicum L. J App Pharm Sci, 2018; 8(08): 092-106. 